\title{
Protein Engineering Approaches to Enhance Fungal Laccase Production in S. cerevisiae
}

\author{
Pablo Aza (1), Felipe de Salas $(\mathbb{D}$, Gonzalo Molpeceres $(\mathbb{0}$, David Rodríguez-Escribano, Iñigo de la Fuente \\ and Susana Camarero* $*$
}

check for updates

Citation: Aza, P.; de Salas, F.; Molpeceres, G.; Rodríguez-Escribano, D.; de la Fuente, I.; Camarero, S. Protein Engineering Approaches to Enhance Fungal Laccase Production in S. cerevisiae. Int. J. Mol. Sci. 2021, 22, 1157. https://doi.org/10.3390/ ijms22031157

Academic Editor: Rebecca Pogni

Received: 22 December 2020

Accepted: 21 January 2021

Published: 25 January 2021

Publisher's Note: MDPI stays neutral with regard to jurisdictional claims in published maps and institutional affiliations.

Copyright: (c) 2021 by the authors. Licensee MDPI, Basel, Switzerland. This article is an open access article distributed under the terms and conditions of the Creative Commons Attribution (CC BY) license (https:// creativecommons.org/licenses/by/ $4.0 /)$.
Microbial \& Plant Biotechnology Department, Centro de Investigaciones Biológicas Margarita Salas (CIB), CSIC, Ramiro de Maeztu 9, 28040 Madrid, Spain; pabloaza@cib.csic.es (P.A.); salasdelacuadra@gmail.com (F.d.S.); gonzalo.molpeceres@cib.csic.es (G.M.); david.rodriguez@cib.csic.es (D.R.-E.); idelafuente011@gmail.com (I.d.1.F.) * Correspondence: susanacam@cib.csic.es

\begin{abstract}
Laccases secreted by saprotrophic basidiomycete fungi are versatile biocatalysts able to oxidize a wide range of aromatic compounds using oxygen as the sole requirement. Saccharomyces cerevisiae is a preferred host for engineering fungal laccases. To assist the difficult secretion of active enzymes by yeast, the native signal peptide is usually replaced by the preproleader of $S$. cerevisiae alfa mating factor $(\mathrm{MF} \alpha 1)$. However, in most cases, only basal enzyme levels are obtained. During directed evolution in $S$. cerevisiae of laccases fused to the $\alpha$-factor preproleader, we demonstrated that mutations accumulated in the signal peptide notably raised enzyme secretion. Here we describe different protein engineering approaches carried out to enhance the laccase activity detected in the liquid extracts of $S$. cerevisiae cultures. We demonstrate the improved secretion of native and engineered laccases by using the fittest mutated $\alpha$-factor preproleader obtained through successive laccase evolution campaigns in our lab. Special attention is also paid to the role of protein $\mathrm{N}$ glycosylation in laccase production and properties, and to the introduction of conserved amino acids through consensus design enabling the expression of certain laccases otherwise not produced by the yeast. Finally, we revise the contribution of mutations accumulated in laccase coding sequence (CDS) during previous directed evolution campaigns that facilitate enzyme production.
\end{abstract}

Keywords: laccase; heterologous production; S. cerevisiae; directed evolution; signal peptide; $\mathrm{N}$-glycosylation; consensus design; synonymous mutations

\section{Introduction}

Laccases are multicopper oxidases that catalyse the oxidation of lignin phenols, aromatic amines and other various organic and inorganic compounds by reducing oxygen to water. Laccases are usually composed of three structural cupredoxin-like domains (D1-D3) each folded into a Greek key $\beta$-barrel topology [1]. Four copper ions (namely T1-T3) are located in two catalytic sites. The mononuclear T1 (blue copper) is located in D3 and serves as the primary electron acceptor site for substrate oxidation; the mononuclear T2 and binuclear T3 copper ions form the trinuclear cluster at the interface between D1 and D3 and function as electron acceptors from T1 prior to the reduction of oxygen [2-4].

Most basidiomycete laccases are monomeric glycoproteins carrying short mannoseenriched glycans linked mostly through $N$-glycosylation, which accounts for $5-25 \%$ of the $\mathrm{Mw}$ of the secreted enzyme. Although the number of putative $N$-glycosylation sites can vary among laccase sequences (according to the presence of the consensus Asn-X-Thr/Ser amino acid sequence), on average fungal laccases are $N$-glycosylated in 2-5 sites [5-7].

The high redox potential of laccases secreted during lignin degradation by wood-rot and litter-decomposing basidiomycete fungi makes these enzymes particularly suited to catalyse the oxidation of a wide range of substrates (phenols, amines, organic dyes, etc) of interest for different industrial sectors [8]. Nevertheless, their remarkable biotechnological potential is hampered by the difficult heterologous expression of basidiomycete 
laccases, making their study and industrial production challenging. Fungal laccases have been expressed in yeast such as Saccharomyces cerevisiae [9-12], Kluyveromyces lactis [13], Yarrowia lipolytica [14] and Pichia pastoris [15-17], and filamentous fungi like Trichoderma reesei [18], Aspergillus oryzae [19] and Aspergillus niger [12,20]. All of them comply with the essential protein post-translational modifications required for the functional expression of recombinant eukaryotic proteins (e.g., formation of disulfide bonds, glycosylation, etc). In addition to its capability to produce and secrete biologically active eukaryotic proteins, S. cerevisiae offers simple growth requirements, with low nutritional demands and short average production time, together with a well-annotated genome, genetic tractability and easy genetic manipulation. What is more, its high frequency of homologous DNA recombination makes this yeast an excellent expression system for enzyme-directed evolution [21]. However, most frequently the protein yields provided by S. cerevisiae are barely sufficient [22].

Recombinant protein production in S. cerevisiae can be promoted by taking advantage of the vast synthetic biology tools developed in this yeast and the availability of genetic elements (promoters, selectable markers, vectors) to design ad hoc expression systems. Other approaches to facilitate the secretion of foreign proteins to the extracellular environment include fine-tuning of post translational modifications like glycosylation or the utilization of yeast secretion factors [23].

Glycosylation plays an essential role in eukaryotic proteins as a major post-translational modification required for correct protein location, folding and biological activity [23]. The $\mathrm{N}$-linked carbohydrate chains in laccases secreted by saprophytic basidiomycete fungi have been described to protect the enzymes from proteases produced by the fungus during wood degradation [24]. Preservation of $N$-glycosylation in several critical sites in fungal laccases has been found to support structural integrity by increasing persistent backbone hydrogen bonds to the protein surface [25]. On the other hand, glycosylation can be a bottleneck for heterologous protein production since differences in the glycosylation pattern between the wild and heterologous host may also result in miss activity of the recombinant protein. For instance, hyperglycosylation, especially excessive mannosylation [26], has been frequently described during production of heterologous proteins in S. cerevisiae, which could affect production titres.

Since the first work in 1983 [27], the preproleader sequence of the $\alpha$-factor mating pheromone of $S$. cerevisiae (MF $\alpha 1$ ) has been widely used to assist the secretion of recombinant enzymes in S. cerevisiae $[12,28,29]$. Furthermore, modification of this secretion peptide by site-directed mutagenesis or directed evolution has resulted in enhanced secretion of the recombinant protein [12,30-32]. For instance, coevolution of the $\alpha$-factor preproleader fused to fungal laccases during enzyme-directed evolution has proved to boost laccase secretion thanks to the mutations accumulated in the signal peptide $[12,28,32,33]$.

Here we present some protein engineering approaches we carried out to facilitate the heterologous production of different basidiomycete laccases by S. cerevisiae. These approaches comprise (i) the use of the best evolved signal peptides obtained in previous laccase-directed evolution campaigns, (ii) the engineering of new $\mathrm{N}$-glycosylation sites in the enzyme, (iii) the consensus enzyme design to introduce conserved amino acid residues that can enhance protein folding and stability; together with a revision of (iv) mutations of certain residues of the protein sequence that were introduced by random mutagenesis and selected during the enzyme-directed evolution in other studies.

\section{Results and Discussion}

\subsection{Use of Evolved $\alpha$-Factor Preproleader Sequences to Raise Laccase Secretion}

Directed evolution in S. cerevisiae of fungal laccases fused to the $\alpha$-factor preproleader resulted in mutated laccase CDS and mutated $\alpha$ leader sequences that notably promoted enzyme secretion by the yeast $[12,28,32,33]$. For instance, during the directed evolution of Pycnoporus cinnabarinus laccase (PcL) for its functional expression in S. cerevisiae, several mutations accumulated in the evolved leader $\left(\alpha_{3 \mathrm{PO}}\right)$ raised 40 -fold the secretion of native 
PcL compared with the levels obtained with the native $\alpha$ leader $\left(\alpha_{\text {nat }}\right)$ [12] from Invitrogen [34]. Then, the evolved $\alpha_{3 \mathrm{PO}}$ leader was later mutated in successive laccase-directed evolution campaigns $[28,29,35]$, giving rise to $\alpha_{9 \mathrm{H} 2}$ leader, which differs in seven mutations (A $\alpha 9 \mathrm{D}, \mathrm{A} \alpha 20 \mathrm{~T}, \mathrm{Q} \alpha 32 \mathrm{H}, \mathrm{F} \alpha 48 \mathrm{~S}, \mathrm{~S} \alpha 58 \mathrm{G}, \mathrm{G} \alpha 62 \mathrm{R}, \mathrm{A} \alpha 87 \mathrm{~T}$ ) from the $\alpha_{\text {nat }}$ leader (Figure 1). The $\alpha_{9 \mathrm{H} 2}$ leader contributed to obtaining the highest yields reported so far for a basidiomycete laccase produced in S. cerevisiae [28]. We evaluate here the secretory potential of $\alpha_{9 \mathrm{H} 2}$ leader as a signal peptide for production in S. cerevisiae of various laccases engineered in our lab. We used as references their own evolved signal peptides (Figure 1), since they have already been shown to improve laccase secretion as compared with the $\alpha_{\text {nat }}$ leader $[12,36]$.

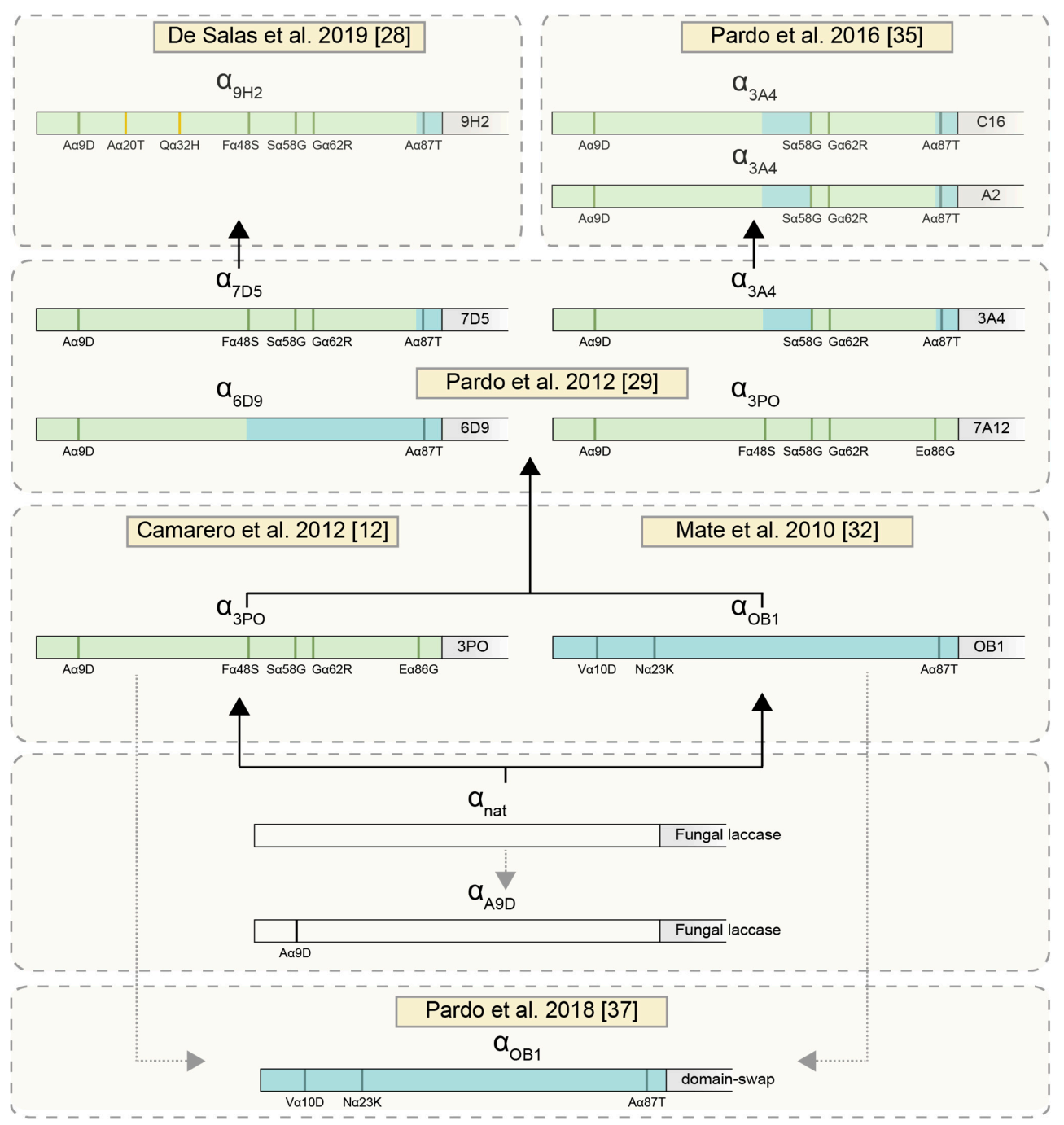

Figure 1. Scheme showing the mutations of the evolved $\alpha$ leaders tested in this study that were accumulated in the $\alpha_{\text {nat }}$ sequence (white) during successive laccase directed evolution campaigns in S. cerevisiae. The names of the evolved $\alpha$ leaders refer to the evolved laccase variant (in grey) with which they were first obtained. First, evolved laccases 3PO and OB1, and their leaders $\alpha_{3 \mathrm{PO}}$ (green) and $\alpha_{\mathrm{OB} 1}$ (blue) were respectively obtained during the directed evolution of P. cinnabarinus [12] and PM1 [32] laccases in S. cerevisiae. The mutations that arose in both evolution pathways are highlighted in green for $\alpha_{3 \mathrm{PO}}$ and blue for $\alpha_{\mathrm{OB} 1}$. Both evolved constructions were later recombined, giving rise to a pool of different chimeric signal peptides and laccases [29]. Afterwards, 3A4 laccase variant was used as template in Pardo and co-workers 2016, obtaining C16 and A2 laccases, both with $\alpha_{3 \mathrm{~A} 4}$ leader [35]. Parallelly, 7D5 was evolved to obtain the final fittest $\alpha_{9 \mathrm{H} 2}$ leader, with the mutation $\mathrm{A} \alpha 20 \mathrm{~T}$ and $\mathrm{Q} \alpha 32 \mathrm{H}$ (indicated in yellow) [28]. The domain-swap laccase was designed by structure-guided DNA recombination to replace the second structural cupredoxin domain (D2) of OB1 laccase by that from 3PO, inheriting the $\alpha_{\mathrm{OB} 1}$ leader [37]. The $\alpha_{\mathrm{A} 9 \mathrm{D}}$ leader was obtained in the current work by site-directed mutagenesis over $\alpha_{\text {nat }}$ (white) as is described in the Materials and Methods section. 
First, we assayed the evolved $\alpha_{9 \mathrm{H} 2}$ leader with the domain-swap laccase, a thermophilic enzyme remarkably stable at high temperature and in organic co-solvents. This enzyme had been designed by structure-guided DNA recombination to replace the second structural cupredoxin domain (D2) of OB1 laccase, obtained during the directed evolution of PM1L for functional expression in S. cerevisiae [32], by that of 3PO laccase (evolved from PcL) [37]. Domain-swap laccase inherited the leader from OB1 laccase $\left(\alpha_{\mathrm{OB} 1}\right.$ leader). We compared the production of the enzyme with its own evolved $\alpha_{\mathrm{OB} 1}$ leader, with $\alpha_{9 \mathrm{H} 2}$ leader, and with $\alpha_{3 \text { Po }}$ leader as one of the first and more improved leaders [12,36]. Since domain-swap laccase is barely produced [12], we dropped the fermentation temperature to $20{ }^{\circ} \mathrm{C}$ to facilitate laccase secretion by slowing down cell growth. While the OD600 was identical in all S. cerevisiae flask cultures, laccase activities detected in the liquid extracts with $\alpha_{9 \mathrm{H} 2}$ leader were 1.3-fold and 1.6-fold higher than those obtained with $\alpha_{3 \mathrm{PO}}$ and $\alpha_{\mathrm{OB} 1}$, respectively (Figure 2).

(a)

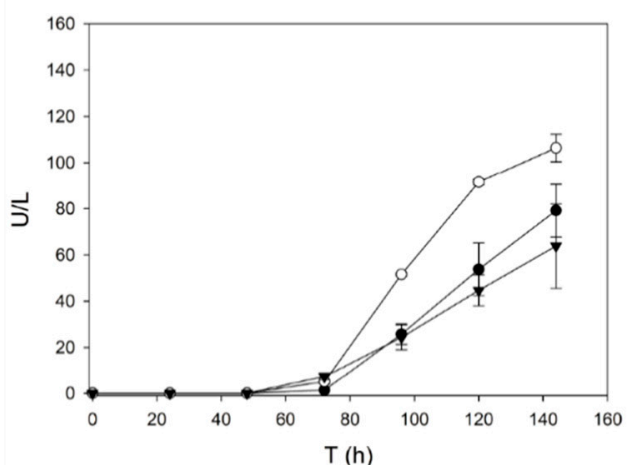

(b)

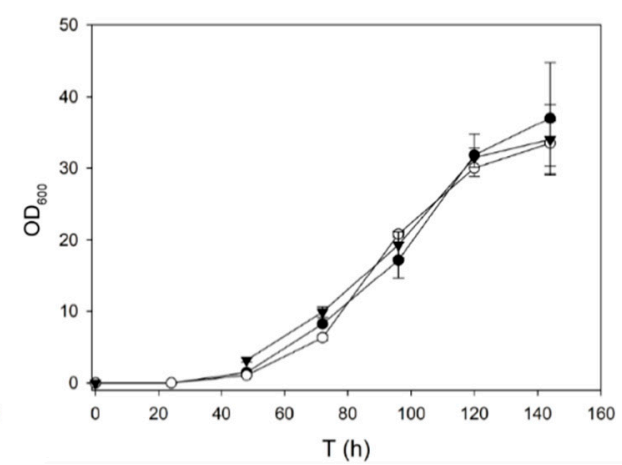

Figure 2. (a) Production of domain-swap laccase by S. cerevisiae flask cultures using its own evolved $\alpha_{\mathrm{OB} 1}$ leader (black triangles), another evolved leader, $\alpha_{3 \mathrm{PO}}$ (black circles), or the evolved $\alpha_{9 \mathrm{H} 2}$ leader lately obtained in our lab (white circles).

(b) Yeast growth (OD 600).

We later confirmed the better performance of $\alpha_{9 \mathrm{H} 2}$ leader over $\alpha_{3 \mathrm{PO}}$ leader for the secretion of $3 \mathrm{PO}$ laccase during S. cerevisiae flask fermentations, this time at $28^{\circ} \mathrm{C}$. Again, both fermentations showed quite similar OD600 curves, suggesting the irrelevant effect of the signal peptide on cell growth. By contrast, laccase production by $S$. cerevisiae was 2 -fold enhanced when the enzyme was fused to $\alpha_{9 \mathrm{H} 2}$ leader (Figure 3).

(a)

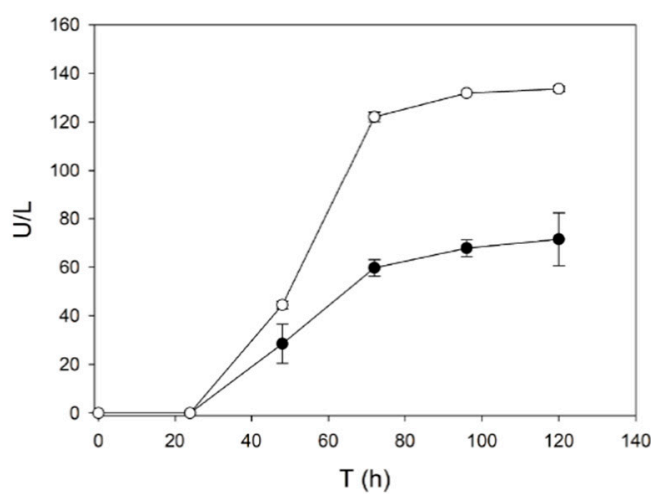

(b)

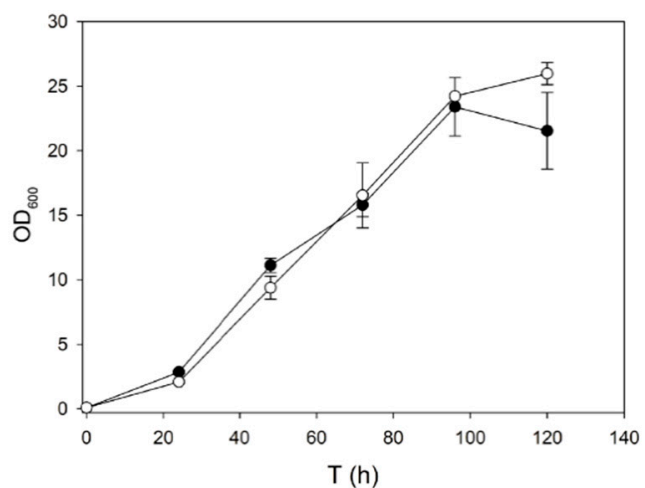

Figure 3. (a) Production of $3 \mathrm{PO}$ laccase by S. cerevisiae flask cultures $\left(28^{\circ} \mathrm{C}\right)$ using its own evolved $\alpha_{3 \mathrm{PO}}$ (black circles) or the final fittest evolved $\alpha_{9 \mathrm{H} 2}$ leader (white circles). Laccase activity is depicted as U/L measured with ABTS, pH 3. (b) Yeast growth (OD 600). 
The superior secretory potential of $\alpha_{9 \mathrm{H} 2}$ leader for laccase production in S. cerevisiae was thereafter compared with other $\alpha$ leader sequences obtained in our lab during other laccase evolution campaigns. For that, we assayed the production of the following laccase engineered variants: 7A12 and 6D9 [29], A2 and C16 [35], fused either to $\alpha_{9 \mathrm{H} 2}$ or to their corresponding evolved $\alpha$ leaders (see Figure 1). In general, laccase activities obtained with $\alpha_{9 \mathrm{H} 2}$ leader were significantly higher, except for A2 laccase, where both signal peptides gave similar results (Figure 4).

(a)

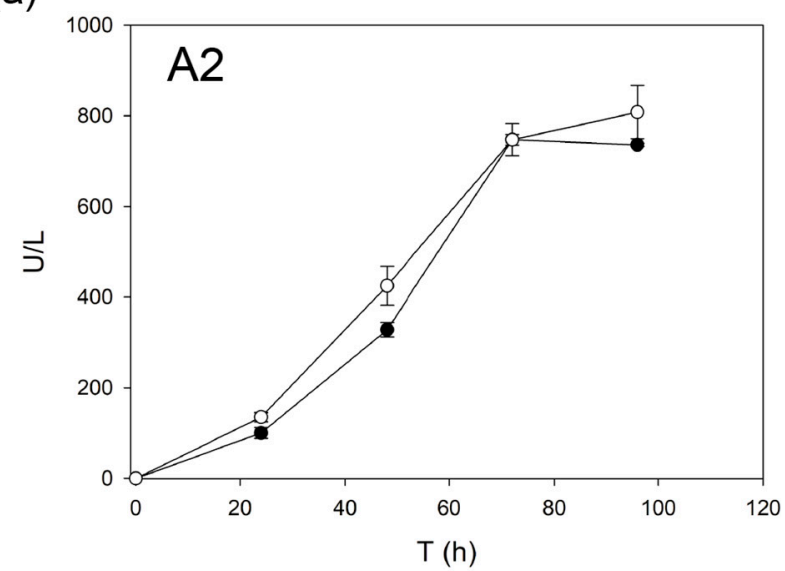

(c)

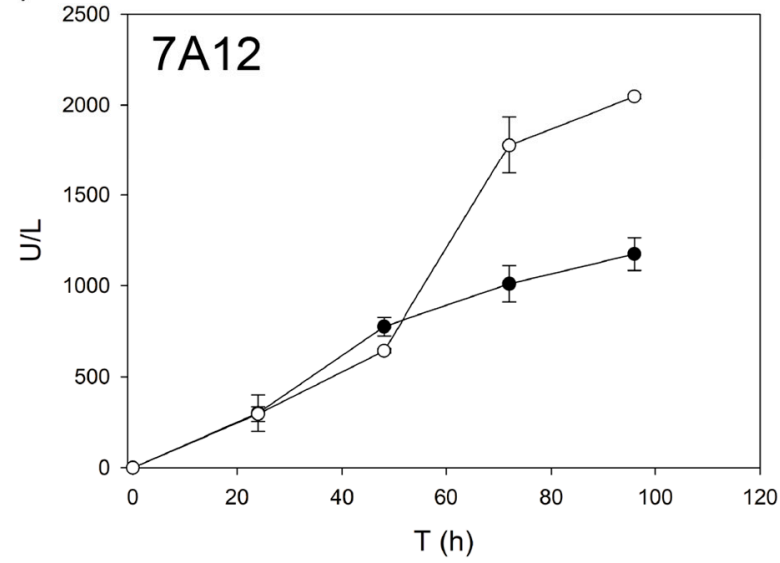

(b)

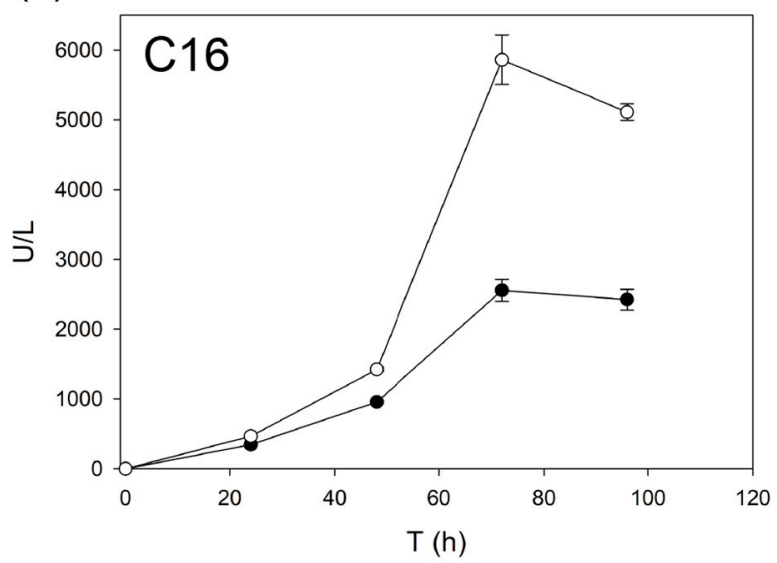

(d)

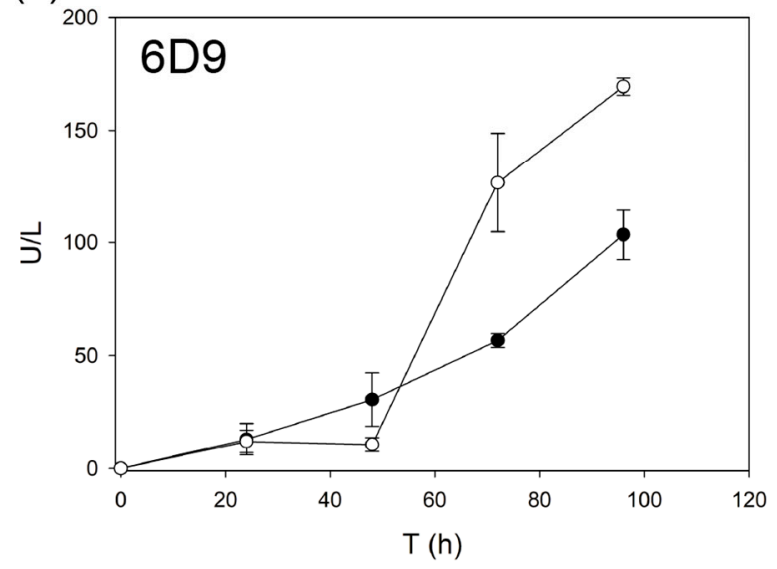

Figure 4. Production of the engineered laccase variants A2 (a), C16 (b), 7A12 (c) and 6D9 (d) using their own evolved $\alpha$ leaders $\left(\alpha_{3 \mathrm{~A} 4}, \alpha_{3 \mathrm{PO}}\right.$ or $\alpha_{6 \mathrm{D} 9}$, black circles) as depicted in Figure 1, or the final evolved $\alpha_{9 \mathrm{H} 2}$ leader (white circles) by S. cerevisiae flask cultures.

Since all the aforementioned laccase variants originated from the same parent laccases (PcL and PM1L, both from Polyporales strains), we aimed to evaluate the secretory potential of $\alpha_{9 \mathrm{H} 2}$ leader to aid the production of laccases from other basidiomycete sources. Two laccases from Agaricales fungi, Agrocybe pediades, ApL (ID 823,363 JGI), and Pleurotus eryngii, PeL (ID 152,153 JGI), were assayed. PeL belongs to the recently classified NLAC that constitute a separate cluster of laccase-like enzymes that are not found in Polyporales [38], whereas ApL is a sensu stricto laccase. The CDS of both laccases were synthesized de novo for expression in S. cerevisiae, replacing the predicted native signal peptides by the $\alpha$-factor preproleader, in particular by $\alpha_{\text {nat }}$ and $\alpha_{9 \mathrm{H} 2}$ leaders. Additionally, we included in the comparison the mutated $\alpha_{\mathrm{A} 9 \mathrm{D}}$ leader, which holds mutation $\mathrm{A9D}$ in the preregion. This mutation (present in $\alpha_{3 \mathrm{PO}}$ leader) had been demonstrated to be responsible for a remarkable improvement of laccase secretion by S. cerevisiae during the directed evolution of PcL [12]. Additionally, a similar mutation in the hydrophobic core of the canonical preregion (V10D) was selected during PM1L engineering [32], and several substitutions on this core also 
enhanced the production of immunoglobulin [30], evidencing its influence in the secretion potential of the signal peptide. The performance of the two mutated signal peptides, $\alpha_{9 \mathrm{H} 2}$ and $\alpha_{\mathrm{A} 9 \mathrm{D}}$, were compared with that of $\alpha_{\text {nat }}$ leader in S. cerevisiae microcultures, and, in order to facilitate laccase detection, we used a minimal expression medium (SEM) to avoid the background of the rich expression medium (EB) used in flask cultures [36]. Detectable ApL activities were obtained with the three $\alpha$ leaders in the supernatants of $S$. cerevisiae microcultures as follows: $\alpha_{\text {nat }}<\alpha_{\mathrm{A} 9 \mathrm{D}}<<\alpha_{9 \mathrm{H} 2}$ (Figure 5). By contrast, no activity could be detected for PeL with any of the three $\alpha$ leaders.

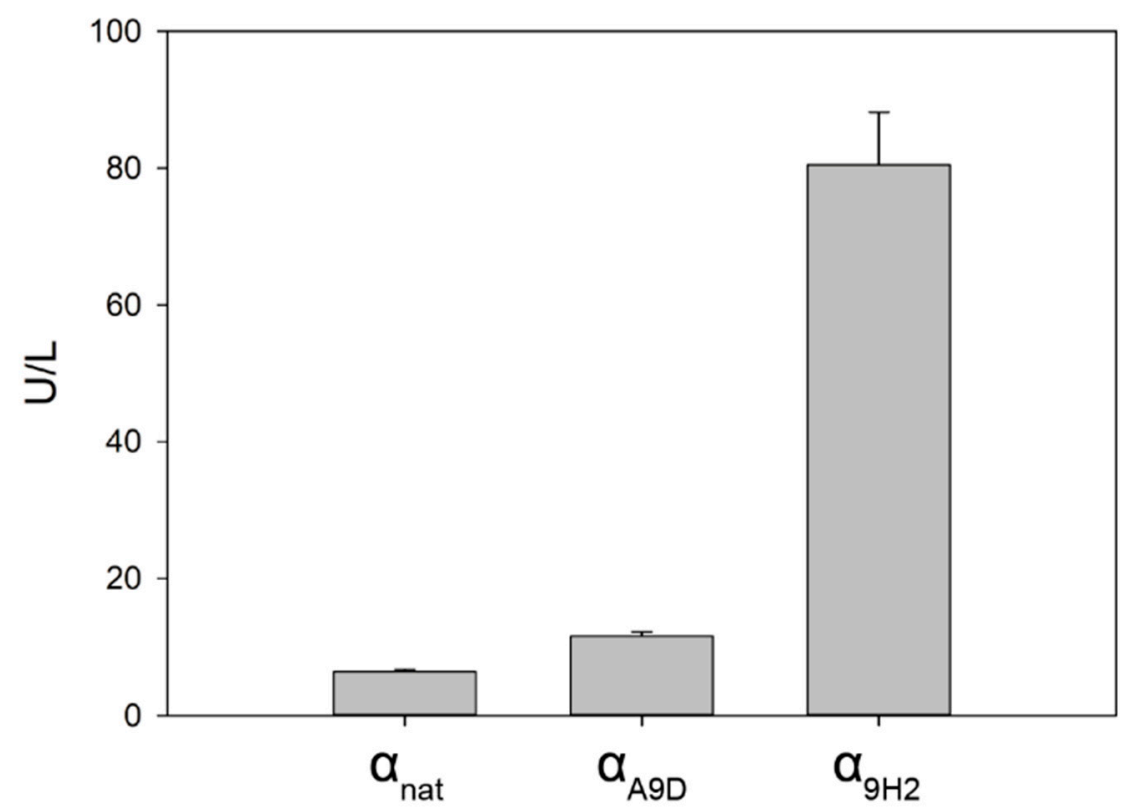

Figure 5. Production of Argocybe pediades lacasse (ApL) fused to either the fittest evolved $\alpha_{9 \mathrm{H} 2}$ leader, the native $\alpha_{\text {nat }}$ leader or the mutated $\alpha_{\mathrm{A} 9 \mathrm{D}}$ leader by $S$. cerevisiae after $48 \mathrm{~h}$ of fermentation in microplates in SEM.

All these results confirmed the suitability of utilising evolved $\alpha$ leaders, in particular $\alpha_{9 \mathrm{H} 2}$, as signal peptides to promote the heterologous production of fungal laccases by S. cerevisiae.

\subsection{Engineering of New N-Glycosylation Sites in the Enzyme}

The domain-swap laccase has three N-glycosylation sites: N54 and N433 located in the first (D1) and third (D3) cupredoxin domains of OB1 laccase evolved from PM1L (see PDB ID: 5ANH [19]), and N215 inherited from D2 of 3PO laccase evolved from PcL (see PDB ID: $2 \mathrm{XYB}$ ). The latter $\mathrm{N}$-glycosylation site seems to be responsible for the hyperglycosylation of the enzyme by S. cerevisiae. The contribution of N215 site as possible determinant for the outstanding thermostability of swap-domain laccase was evaluated in the deglycosylated variant N215G. It was proved that extra glycosylation in this site was not responsible for the improved thermostability of the enzyme [37]. On the contrary, removal of the N215 site strictly diminished the laccase activity detected in the supernatants of $S$. cerevisiae cultured in flasks (Figure 6), suggesting a possible role of $\mathrm{N}$-glycosylation in the heterologous production of the enzyme.

Taking the aforesaid into account, we addressed the lack of expression of PeL by analysing the $\mathrm{N}$-glycosylation sites in this enzyme. Three putative $\mathrm{N}$-glycosylation sites were found in PeL: N89, N256 and N436, respectively located in domains D1, D2 and D3. We analysed the $N$-glycosylation sites in the 25 NLAC sequences found in the 52 fungal genomes previously studied [38]. We observed that N89 and N436 were largely conserved in NLAC sequences, as well as in basidiomycete laccases sensu stricto, whereas N256 was much less frequent. Conversely, the majority of NLAC held the N220 site, also located in 
D2 (Figure 7). Hence, we introduced by site-directed mutagenesis a new $\mathrm{N}$-glycosylation site in 220 position of PeL in an attempt to improve the particularly difficult expression of the enzyme in $S$. cerevisiae. The $\alpha_{9 \mathrm{H} 2}$-PeL construction was used as a template to introduce the PeL K220N variant and their heterologous expression was tested in S. cerevisiae microcultures. The additional $\mathrm{N}$-Gly site introduced in PeL enabled the functional expression of the enzyme by $S$. cerevisiae, detecting significant laccase activity levels in the supernatants of $S$. cerevisiae microcultures (Figure 8).

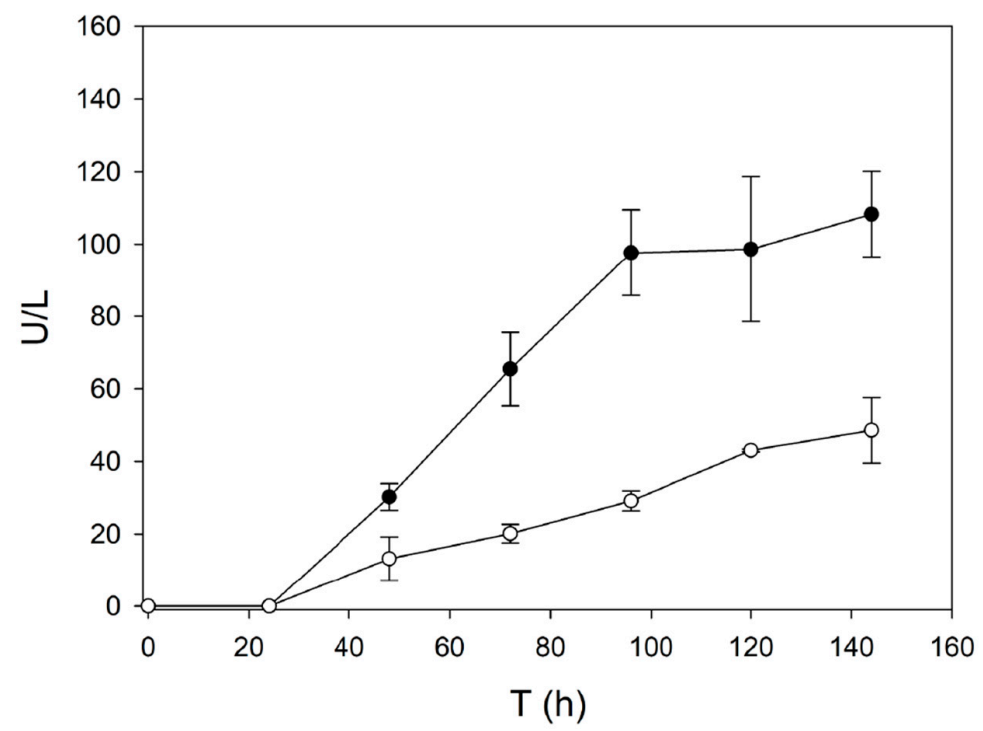

Figure 6. Production of domain-swap laccase (black circles) and its deglycosylated variant N215G (white circles) by S. cerevisiae cultured in flask. In both cases the evolved $\alpha_{9 \mathrm{H} 2}$ leader was used as signal peptide.

\begin{tabular}{|c|c|c|c|c|}
\hline \multirow[b]{2}{*}{ ID Laccase (JGI) } & \multicolumn{4}{|c|}{ N-glycosylation sites } \\
\hline & N89 & K220 & N256 & N436 \\
\hline AB2139148 & PQPPNTTFTYEF & FSVDNHNLTFME & ILNANQPVDNYW & INGGNTTFRFFT \\
\hline AB2146228 & PQPPNTTFTYEF & FSVDNHSLVFME & ILHANQPIDNYW & INGGNTTFRFFT \\
\hline AE11490 & PIPPKSTFDYAF & FSIDNHNISAME & ILEASQPIGNYW & INGGNTTFRFFS \\
\hline AE4923 & PIPPNNTFDYAF & FSIDNHNITAME & ILHADQPIDNYW & VNGGNLTFRFKS \\
\hline CG1433292 & PIPPNTTFLYEF & LSFDNHTFDVME & ILNANQTVGNYW & INGGNTTFRFFS \\
\hline CG1433318 & PIPPNTTFLYEF & LSFDNHTFDVME & ILHANQTVGNYW & INGGNTTFRFFS \\
\hline CG1433884 & PIPPNTTFLYEF & FSVDNHTFDVME & ILNANQTVDNYW & VTSGNTTFRFFS \\
\hline GL235696 & PIPPGDTFHYAF & WSIDNHNLTVME & IVEANQPVDNYW & INGGNTTFRFKA \\
\hline GL94992 & PIPPNETFHYAF & WSIDNHNLTVME & VVEANQPVNNYW & INGGNTTFRFKA \\
\hline HA163392 & PIAPNSTFLYQY & FSVDNHNLTVIE & ILHANQPVDNYW & VNGGNTTFRFFS \\
\hline HR1131352 & PVAPGDDFTYSF & FSIDNHLMDAME & IVKADQPVGNYW & INGGNTTFRFFT \\
\hline HR1140715 & PIAPGADFTYAF & FSVDSHNLTAIE & ILEANQPIDNYW & VNGGNMTFRFFT \\
\hline LG51322 & PIPPNTTFVYDF & FSIDNHNITFME & ILNANQPVNNYW & INGGNTTFRFLT \\
\hline LN125975 & PIPPNTTFTYAF & FSIDSHNITFME & VLHANQPVDNYW & INGGNTTFRFFS \\
\hline MF670459 & PIPPNTTFTYEF & FSIDGHNVTFME & ILNANQPVDNYW & IN-GNTTFRFFS \\
\hline MF673643 & PIPPNTTFVYDF & FSIDNHNITFIE & ILNANQPVNNYW & INGGNTTFRWMT \\
\hline MF727632 & PIPPNTTFVYDF & FSVDGHNMTFIE & VLNANQPVGNYW & INGGNTTFRFFT \\
\hline MF794473 & PIPPNTTFNYQF & FSIDNHNITFME & ILNATQPVNNYW & INGGNTTFRWMT \\
\hline MI238963 & PIPPGNDFHYVF & FSIDSHNITAIE & VLEANQPVDNYW & VNGGNMTFRFKS \\
\hline MI942182 & PIPPGNVFHYAF & FSVDNHNITVME & ILNANQPVGNYW & INGGNTTFRFKA \\
\hline OM1440713 & PVAPGDDFTYSF & FSIDNHLMDAME & IVKADQPVGNYW & INGGNTTFRFFT \\
\hline OM1527120 & PIAPGADFTYAF & FSVDSHNLTAIE & ILEANQPIDNYW & VNGGNMTFRFFT \\
\hline PE1521536 & PIPPNSTFLYDF & FSIDKHTFDAIE & IVNANQTIDNYW & INGGNTTFRFFS \\
\hline$\overline{\mathrm{PO} 1067328}$ & PIPPNSTFLYDF & FSIDNHTFDAIE & IVHANQTIDNYW & INGGNTTFRFFS \\
\hline SR150877 & PIPPNTTFTYEF & FSIDQHNLTVIE & IVNASQPVDNYW & INGGNTTFRFFS \\
\hline
\end{tabular}

Figure 7. Sequence alignment of the 25 NLAC found in Agaricomycotina compared with Pleurotus eryngii laccase (PeL) sequence (PE1521536 in bold, underlined), showing the NXT/S motifs that account for putatively conserved $N$-glycosylation sites (in green, underlined). 


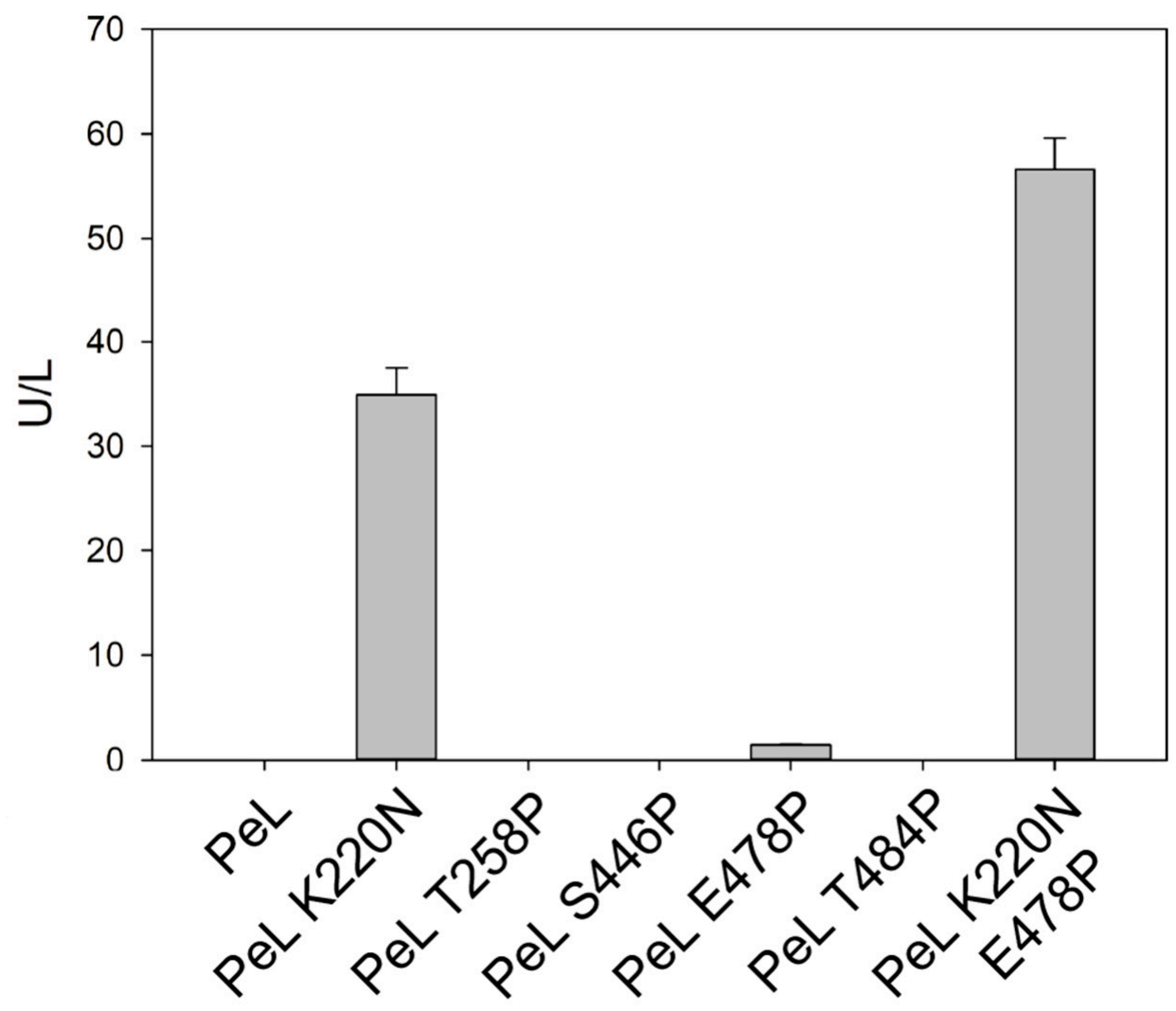

Figure 8. Production of PeL and its glycosylation variant (PeL K220N) and other PeL variants built by replacing certain residues by consensus Pro. The evolved $\alpha_{9 \mathrm{H} 2}$ leader was used as signal peptide in all cases. Laccase activities were measured with ABTS pH 3 after 48 h of S. cerevisiae fermentation in microplates in SEM.

The N220 site introduced in PeL is analogous to the N215 site of the domain-swap laccase, and it is conserved in $40 \%$ of the Polyporales laccases studied [38], supporting the possible contribution of glycosylation in this site for proper laccase production. This $\mathrm{N}$ site is not present in Agrocybe pediades laccase (ApL). Nevertheless, from the three $\mathrm{N}$ glycosylation sites predicted in ApL (N21, N255 and N439, each respectively located in a different laccase domain), N255 in D2 coincides with the aforementioned N256 site of PeL. When we removed N255 site from ApL variant by site-directed mutagenesis, the laccase activity found in S. cerevisiae flask fermentations was significantly reduced (over 6 times); in both cases, $\alpha_{9 \mathrm{H} 2}$ leader was used as signal peptide (Table S1).

The crucial role of certain $\mathrm{N}$-glycosylation sites in laccases seems to be rather related to their location in the protein, which determines that its addition or removal cause a profound conformational change [7]. For instance, from the three $\mathrm{N}$-glycosylation sites (N75D, N238D or N458D) of Lentinus Lcc4 (produced in Pichia pastoris), the removal of glycosylation in N238 and N458 sites caused a significant loss of activity detected in the yeast culture supernatants. The N458 site is highly conserved (N439 in ApL and N436 in PeL), whereas the N238 site is analogous to the conserved N220 in NLAC. In Lentinus, laccase glycans linked at N458 (located in D3) and N238 sites (in D2) interact directly with a lengthy loop which crosses over the two laccase domains, connecting D2 and D3. The authors hypothesised that the H-bond networks between the loop and the glycan moieties play a crucial role on protein activity that was severely reduced with the removal of these $\mathrm{N}$-glycosylation sites [7]. However, in our opinion it is difficult to discriminate whether this is the result of inferior catalytic activity or reduced enzyme production, since no kinetic data were provided. Nevertheless, the results obtained here by introducing the new N220 site in PeL and removing N215 in domain-swap laccase (both analogous to N238 in Lentinus Lcc4) coincide to point out the crucial role of $\mathrm{N}$-glycosylation in this 
site. Moreover, it seems that laccases lacking the N238 site present nearby alternative glycosylation sites in D2 such as N255 in ApL, whose removal drastically reduced the laccase activity detected in S. cerevisiae cultures (Table S1). To assess the real contribution of glycan anchoring in this position to enzyme activity or production, we purified ApL variants before and after removal of the N255 site for their characterisation. SDS-PAGE of both ApL variants demonstrated that the $\mathrm{N} 255$ site is not putative but a real $\mathrm{N}$-glycosylation site and, therefore, its removal produced a deglycosylated variant (Figure S1). Additionally, when we measured their catalytic constants, we observed a detrimental effect on enzyme activity in the deglycosylated variant ( $k_{\text {cat }}$ was reduced 2-fold) (Table S2). However, this only partially explained the 6-fold diminished activity detected in the liquid extracts as compared with the non-deglycosylated variant (Table S1). Thus, the positive effect of glycosylation in D2 for laccase production by S. cerevisiae was evidenced, as well as in laccase catalytic activity.

Actually, the influence of $\mathrm{N}$-glycosylation on the functionality of fungal laccases is a complex issue not yet fully understood. It seems to have a substantial role in fine-tuning enzymatic properties such as catalytic activity in wild laccases produced by basidiomycete strains $[39,40]$. On the other hand, changes in the glycosylation pattern through laccase heterologous expression in yeast have been reported to either improve enzyme stability, or change substrate affinity or activity [41,42] due to the addition of large glycan chains to the protein backbone. However, in our experience, laccase hyperglycosylation by $S$. cerevisiae does not contribute to improve the stability of the enzyme [37], in agreement with other studies [7]. Moreover, hyperglycosylation of fungal laccases by this yeast occurs only with certain laccases and is not necessarily correlated with a decrease of secreted enzyme activity coinciding with other results [43]. In fact, here we provide evidence that addition of new $\mathrm{N}$-glycosylation sites can stimulate the production of properly folded and active laccases by S. cerevisiae, in concordance with already reported production of other heterologous proteins [44], especially when they are impaired in secretion due to aggregation [45].

\subsection{Consensus Enzyme Design}

The introduction of the N220 site in PeL is part of the consensus design we followed in an attempt to facilitate the difficult heterologous expression of the enzyme by exploiting the evolutionary information encapsulated in homologous NLAC sequences [38]. Consensus protein design is based on the hypothesis that, at a given position, the respective consensus amino acid contributes more than the average to the stability of the protein than nonconserved ones [46]. It has shown high success rates in creating well-folded and stable proteins that retain biological activities.

The mature sequence of PeL was compared with the consensus sequence obtained from the multiple alignment of the 25 NLAC sequences found in 52 Agaricomycotina genomes [38]. We searched for putatively conserved $\mathrm{N}$-glycosylation sites and proline residues that were absent in PeL. We detected one consensus Asn residue participating in a putatively conserved $\mathrm{N}$-glycosylation site (Figure 7) and selected four consensus proline residues (Figure 9) placed in the protein surface in positions distant from the active site (Figure 10). These amino acid residues were individually introduced in PeL through site-directed mutagenesis to obtain the single mutated PeL K220N, T258P, S446P, E478P and $\mathrm{T} 484 \mathrm{P}$ variants that were fused to $\alpha_{9 \mathrm{H} 2}$ and expressed in S. cerevisiae. In addition to the aforesaid remarkable effect of mutation $\mathrm{K} 220 \mathrm{~N}$ (see previous subsection), consensus mutation E478P also enabled to obtain detectable laccase activity levels in the supernatants of the yeast microcultures. Conversely, none of the other single mutations provided detectable laccase activities (Figure 8). We combined mutations K220N and E478P in $\mathrm{PeL}$ and observed a positive synergism between both mutations that was reflected in the higher levels of activity secreted by S. cerevisiae microcultures (Figure 8 ) and in the superior thermostability of the double-mutated variant in comparison with PeL K220N (Table 1). 


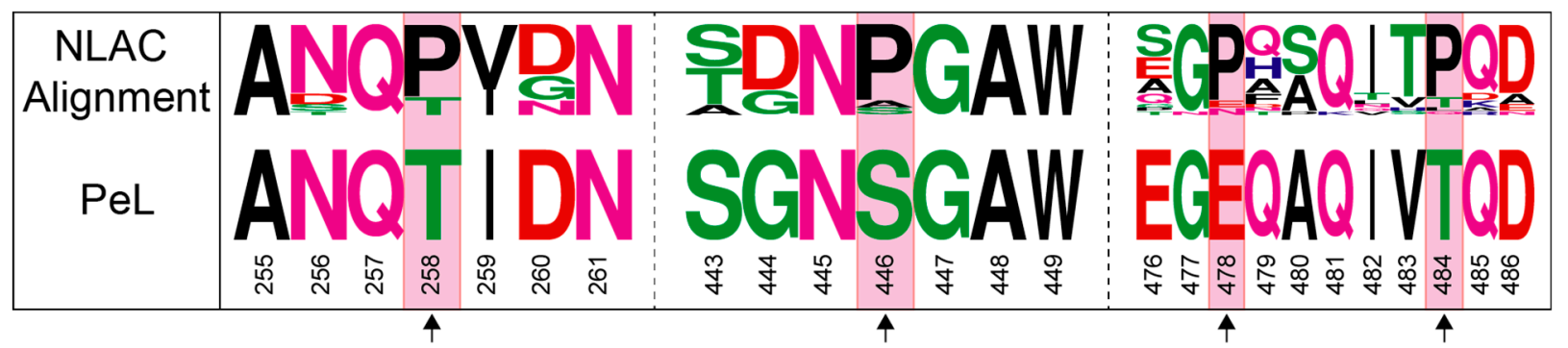

Figure 9. Sequence logo for the 25 NLAC sequences found in Agaricomycotina compared with PeL (NLAC) sequence showing the conserved surface Pro that were, respectively, introduced in PeL through mutations T258P, S446P, E478P, T484P.

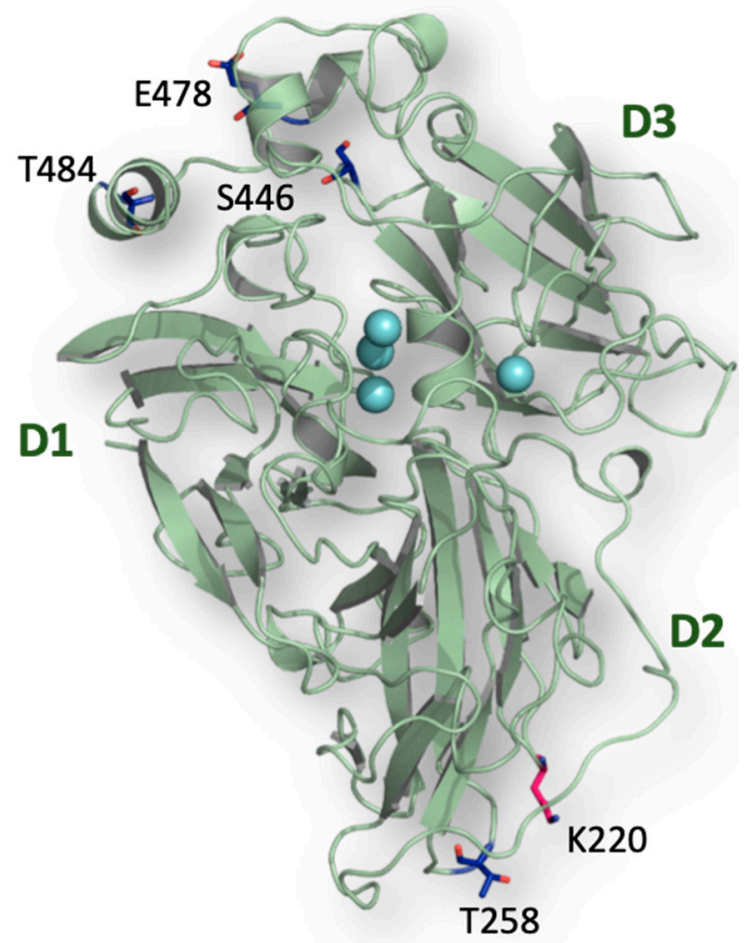

Figure 10. Structure of PeL (modelled with PDB ID: 3PXL as the template) showing the location of the residues that were mutated to introduce a consensus $N$-glycosylation site $(\mathrm{K} 220 \mathrm{~N})$ and several consensus Pro residues on the surface of the protein through mutations T258P, S446P, E478P and T484P.

Table 1. Thermostabilities as T50 (10 min) values and stabilities after $24 \mathrm{~h}$ incubation at different $\mathrm{pH}$ (indicated as \% of the initial activities) of the PeL variants obtained by consensus design.

\begin{tabular}{cccccc}
\hline PeL Variant & T50 $\left({ }^{\circ} \mathbf{C}\right)$ & pH 3 & pH 5 & pH 7 & pH 9 \\
\hline K220N & $46 \pm 0.5$ & - & - & - & - \\
K220N, E478P & $49 \pm 0.1$ & $23 \pm 3$ & $93 \pm 8$ & $88 \pm 5$ & $85 \pm 1$ \\
K220N, E478P, & $47 \pm 0.1$ & $15 \pm 1$ & $93 \pm 2$ & $100 \pm 1$ & $84 \pm 2$ \\
$\begin{array}{c}\text { T484P } \\
\text { K220N, S446P, }\end{array}$ & $43 \pm 0.2$ & $32 \pm 1$ & $95 \pm 2$ & $92 \pm 1$ & $83 \pm 1$ \\
E478P & & &
\end{tabular}

Then, we constructed over PeL K220N, E478P (i) three triple mutants by introducing separately mutations T258P, S446P or T484P, and (ii) a quintuple mutant by introducing the three mutations together. The production curves of the multiple variants by $S$. cerevisiae flask cultures were compared with the production of the double-mutated variant (Figure 11). The quintuple-mutated variant rendered almost undetectable laccase activity. Introduction 
of mutation T258P in the corresponding triple variant did not significantly affected enzyme activity levels as compared with the double-mutated variant, whereas S446P severely impaired them. The latter mutation also strongly reduced laccase thermostability (Table 1). By contrast, we found a notable increment of laccase activity levels for the PeL K220N, E478P, T484P variant, although the thermostability of the enzyme was somehow reduced. The double- and triple-mutated laccase variants were stable at neutral and alkaline $\mathrm{pH}$ but much less stable at $\mathrm{pH} 3$ (Table 1).

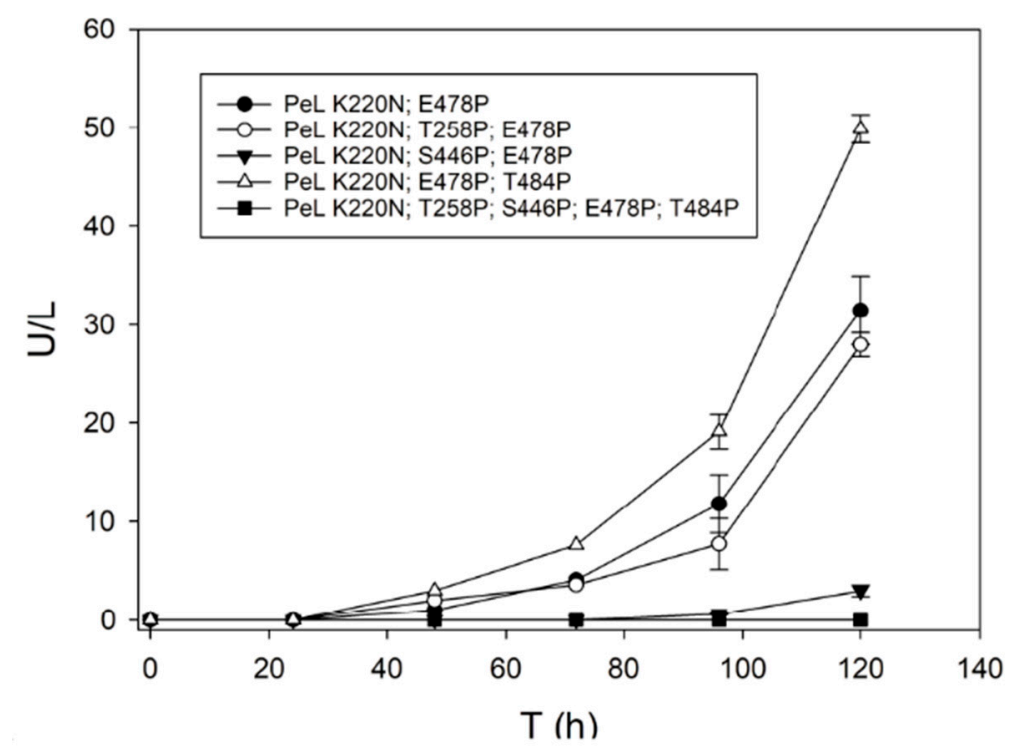

Figure 11. Production by S. cerevisiae cultured in flask of the double-, the three triple- and the quintuple-PeL mutated variants obtained by consensus design. All laccase sequences were fused to $\alpha_{9 \mathrm{H} 2}$ leader as signal peptide.

The molecular mechanisms involved in protein stability include, among others: disulphide bridges, ion pairs, hydrogen bonds, hydrophobic interactions, packing, decrease of the entropy of unfolding state and inter-subunit interactions [47]. After consensus design, enzymes show improved thermodynamic stability and increased robustness of the native structure to assure the minimal stability required to fold $[48,49]$. We were not able to determine if consensus N220 site improved the thermal stability of PeL due to the lack of expression of the native enzyme. However, glycosylation in the N220 site seems to have a positive impact on the production of the folded enzyme, in agreement with that found for Lentinus lcc4 [7] (see previous subsection). On the other hand, Pro is the amino acid with the lowest conformational entropy due to the rigidity of the pyrrolidone ring. The introduction of consensus proline residues would decrease the backbone entropy of the PeL unfolding state, thus contributing to the increase in the free energy change for protein thermostabilization [50]. However, not every Pro introduced in PeL stabilised the enzyme, most probably due to the different environments of the mutated sites. This fact agrees with recent consensus design of OB1 laccase where several consensus mutations incremented thermostability and secretion, but others resulted neutral and deleterious [51].

It has been estimated that the stability of the native form of a protein increases by about $2-4 \mathrm{~kJ} / \mathrm{mol}$ when a proline residue is introduced into a protein chain at a location that does not alter the protein structure [50]. However, if proline accommodation imposes some regional strain or unfavourable steric contact, it results in protein destabilization $[52,53]$. The three mutations S446P, E478P and T484P introduced in PeL reduced the number of polar interactions with neighbour residues (Figure 12), although they produced dissimilar effects. Prolines 446 and 484 were introduced in a loop and in the N-terminus of an $\alpha$ helix, respectively; both are common locations for proline in proteins. However, Pro 446 had a strong negative impact on the thermostability and production/activity of the 
enzyme, whereas Pro 484 notably boosted the laccase activity levels secreted in S. cerevisiae cultures (Figure 11 and Table 1). Conversely, laccase production and thermostability were significantly raised by the consensus Pro 478, despite it interrupting a putative salt bridge between E478 and R369 and one H bond with Q479. In addition, the location of Pro 478 in the middle of an $\alpha$ helix is considered as a destabilizing feature of protein structure. The change in free energy of folding for introducing Pro in $\alpha$ helix is about $14 \mathrm{~kJ} / \mathrm{mol}$ [54], and the presence of proline residues in an $\alpha$-helix has been regarded as problematic because of their ability to break its structure (there are several reports of proline mutations as a pathogenic mechanism) [55].
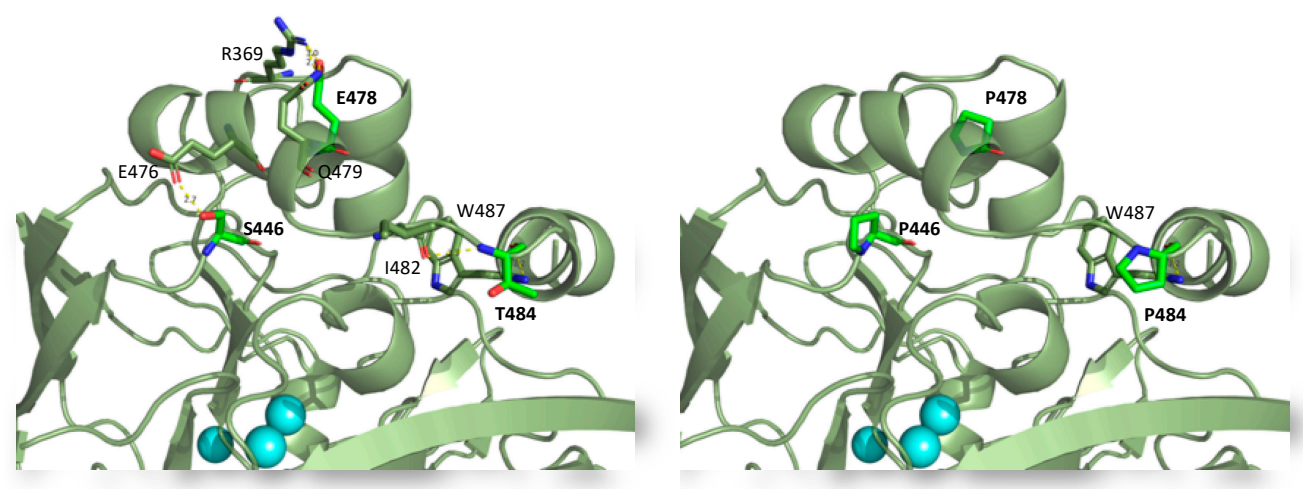

Figure 12. Detail of PeL structure model showing the polar contacts of residues 446, 478 and 484 before and after being mutated to consensus Pro.

Nevertheless, even when the kinked proline-containing helix can be considered a rare feature, they are not all that uncommon in some globular proteins (e.g., transmembrane proteins), where a range of kink angles and a variety of hydrogen bonding schemes have been found [54], suggesting a function related to conformational flexibility [56]. Prolines in $\alpha$-helices are one of the unique characteristics of karyopherins and some other HEAT repeat-containing proteins able to pass through the amphiphilic matrix of the nuclear pore complex [57]. In karyopherins, proline does not serve as a "breaker" of $\alpha$-helical proteins, but rather behaves as a "protector" of the flexible molecular conformation of the protein to achieve efficient nuclear transport [58]. The local destabilization of $\alpha$-helices finally contributes to maintain the overall molecular structure. In line with this, we recently demonstrated that mutations of the laccase C-terminal producing a loosening of $\alpha$ helix secondary structure and increasing the mobility of the region, strongly improved the stability of the enzyme against thermal denaturation [28]. The higher flexibility of the C-terminal helped neutralize the destabilization caused by thermal fluctuations at high temperatures, which could allow the rest of the protein to maintain the native structure and remain active.

Finally, since proline can exist in cis- and trans-configuration, the contribution of a specific proline residue to protein stability is associated with the thermodynamic equilibrium between cis- and trans-isomers of the peptide bond between Pro and its preceding residue [59]. In PeL in particular, a Gly residue (strictly conserved in NLAC) precedes Pro 478 (Figure 9). Glycine appears with high propensity at pre-cisPro positions in proteins, rescuing secondary structures from severe distortions. The Gly-cisPro motif is evolutionarily conserved, functionally important and dynamic in nature [60,61].

\subsection{Mutations Accumulated in the Protein CDS during Directed Evolution}

Mutations accumulated in the protein CDS during directed evolution in S. cerevisiae might be advantageous for the heterologous expression of the recombinant enzyme. Some of these mutations are synonymous mutations that remain at the nucleotide level, without affecting the amino acid sequence of the protein, but can significantly influence protein abundance through changes in translation efficiency. On the one hand, they can pro- 
vide a change to a synonymous codon more frequently used in the heterologous host. Synonymous mutations favouring codon usage in S. cerevisiae were selected during the directed evolution of fungal laccases from Myceliophthora thermophila, Trametes sp, PM1 basidiomycete and P. cinnabarinus $[12,32,33,62,63]$ carried out in this yeast. The accumulation of synonymous mutations in the CDS of the final evolved enzymes would favour the bias toward a specific subset of codons (related to the levels of the corresponding tRNAs in the eukaryotic apparatus) and, consequently, speed up the elongation rate by avoiding translation pauses [64]. Another suggested mechanism by which synonymous mutations can modulate protein abundance is the folding energy of the mRNA transcript, which may influence ribosome binding and therefore translation initiation [65].

Substitutions of amino acid residues in the mature protein can also influence enzyme production by improving protein folding and maturation in addition to a possible contribution to protein robustness. Several beneficial mutations of amino acid residues exposed in the surface of distal protein regions, far away from the catalytic site, have been discovered during laccase engineering and associated with improvements in enzyme secretion by S. cerevisiae. For instance, during the in vitro evolution campaigns of laccases from PM1 basidiomycete [32] and P. cinnabarinus [12] toward functional expression by the yeast, we selected mutations in similar distal locations of D2, respectively, in residues Asp281 and Arg280. Both mutations induced conservative amino acid replacements ( $\mathrm{R} 280 \mathrm{H}$ and D281E), and both interrupted several hydrogen bonds with neighbour residues, thereby enhancing the flexibility of this region, which might facilitate protein folding during the post-translational stages.

During different enzyme evolution campaigns of $M$. thermophila laccase $(\mathrm{MtL})$ in S. cerevisiae, mutation of residue 552 to Asn was repeatedly selected. This residue is located in the surface of the laccase, in a loop far away from the catalytic pocket. Asn was first selected during the directed evolution of the enzyme for expression in S. cerevisiae, through mutation $\mathrm{Y} 552 \mathrm{~N}$ [33]. Later on, during MtL evolution for the synthesis of polymeric dyes, mutation H552N was unexpectedly selected [63]. This mutation recovered the Asn that had been lost in an intermediate evolution campaign and contributed to obtaining a final production yield of $37 \mathrm{mg} / \mathrm{L}$ of this ascomycete laccase. Thus, the presence of asparagine in this position has been associated with the improved functional expression of the enzyme by this yeast (even it is not related to the addition a $\mathrm{N}$-glycosylation site). Another recent example of a mutation placed in a flexible loop, far from the T1 site, and exposed to the protein surface, is that we recently selected in residue 159 during the directed evolution of $A$. pediades laccase. The mutation was responsible for a 3-fold increment in the activity detected in the liquid extracts of $S$. cerevisiae cultures. Since this mutation did not change the activity of the enzyme towards different substrates, it has been related with an improvement in enzyme production (unpublished data).

Finally, it is worth mentioning that mutations contributing to enzyme production are not always located in distal loops of the protein. This was the case of Phe 454 substitution to Pro located in the active site of RY2 laccase, which was developed in our lab through directed evolution and computational design and constitutes a robust biocatalyst for green chemistry [28]. Despite the F454P mutation being contiguous to His 455 ligand of T1 copper, it did not modify the kinetic activity of the enzyme. By contrast, it was associated with an increase of laccase production from $16 \mathrm{mg} / \mathrm{L}$ to $25 \mathrm{mg} / \mathrm{L}$. This mutation was selected from the saturation mutagenesis of position 454. Even though different amino acid substitutions led to significant improvements in the detected activity, only Pro did not severely impair the stability of the enzyme, even when it was placed in the middle of an $\alpha$ helix [28].

\section{Materials and Methods}

\subsection{Reagents and Strains}

Yeast Transformation Kit was purchased from Sigma-Aldrich (St. Louis, MO, USA). High Pure Plasmid Isolation Kit and ABTS (2,2'azinobis (3ethylbenzothiazoline- 6 sulphonic acid)) were obtained from ROCHE. Phusion High-Fidelity DNA polymerase and Restriction 
enzymes (NotI and BamHI) were obtained from New England Biolabs. QIAquick gel extraction kit from Qiagen (Hilden, Germany)). Zymoprep ${ }^{\mathrm{TM}}$ Yeast Plasmid Miniprep II was purchased from Zymo Research (Tustin, CA, USA). S. cerevisiae BJ5465 strain was purchased from LGC Promochem (Barcelona, Spain). The $\alpha$-factor preproleader $\left(\alpha_{\text {nat }}\right)$ was obtained from the pPICZ $\alpha$ family of plasmids of Invitrogen (Waltham, MA, USA).

\subsection{Culture and Media}

Minimal Medium (MM) and EB expression medium were prepared as previously described [12]. SEM expression medium was prepared as previously described [36], without adding ethanol. Four or $2 \mathrm{mM} \mathrm{CuSO}_{4}$ were added for laccase expression in EB and SEM media, respectively.

\subsection{Predictions and Modelling}

Prediction of $\mathrm{N}$-glycosylation sites was performed using the NetNGlyc 1.0 Server (http://www.cbs.dtu.dk/services/NetNGlyc/). The PeL 3D model was built with the Swiss-model server [66] using Trametes hirsuta laccase structure (PDB ID: 3PXL) as template. The analysis of mutations of the mature protein and representation of 3D protein structures were performed using PyMol. Putative signal peptide was analysed with SignalP-5.0 Server [67]. The graphical representations of amino acid frequency for the searching of consensus prolines were done with WebLogo [68].

\subsection{Laccase Variants and Libraries Constructions in S. cerevisiae \\ 3.4.1. Signal Peptides}

The CDS of Pleurotus eryngii laccase (JGI ID: 152153) and Agrocybe pediades laccase (ID 823,363 JGI) were optimized for codon usage in S. cerevisiae with the OPTIMIZER Web server using the random guided method [69] and synthesised de novo by ATG Biosynthetic fused to the sequence of $\alpha_{\text {nat }}$ leader. Laccases 7A12 [29], 6D9, A2 [35] domain-swap [37] and $3 \mathrm{PO}$ [12] were obtained from our collection of enzymes engineered in S. cerevisiae; all cloned in the uracil-independent and ampicillin-resistant vector pJRoC30 with their respective evolved $\alpha$ leaders.

Overlapping ends primers were designed for ApL and PeL cloning in $\mathrm{pJRoC} 30$ vector (Table S3). Two independent PCR reactions were carried out with the general ExtFw sense primer, and a specific antisense primer for PeL (PeL-pJRoC Rv) and ApL (ApL-pJRoC Rv). The $\mathrm{pJRoC} 30$ vector was digested with NotI and BamHI, and the resultant linearized vector was co-cloned with given PCR products to obtain the $\alpha_{\text {nat }}-\mathrm{PeL}$ and $\alpha_{\text {nat }}$-ApL constructions by In Vivo Overlap Extension (IVOE) in S. cerevisiae [70].

For fusing different signal peptides to different laccase variants, a first fragment was obtained by PCR with ExtFw sense primer and 87Final-Rv antisense for $\alpha_{9 \mathrm{H} 2}$ or $86 \mathrm{Final}-\mathrm{Rv}$

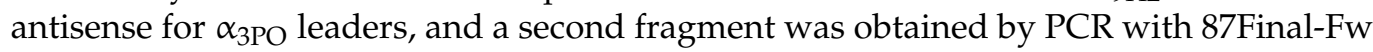
sense for $\alpha_{9 \mathrm{H} 2}$ or 86 Final-Fw sense for $\alpha_{3 \mathrm{PO}}$ and ExtRv antisense primer (Table S3). The two PCR fragments were co-cloned as explained above.

The $\alpha_{\mathrm{A} 9 \mathrm{D}}-\mathrm{PeL}$ and $\alpha_{\mathrm{A} 9 \mathrm{D}}-\mathrm{ApL}$ variants were obtained as follows: using their respective $\alpha_{\text {nat }}$ leader constructions two PCR were performed as aforesaid; a first fragment with ExtFw sense and A9D Rv antisense primers and a second fragment with A9D Fw sense and Ext Rv antisense primer. The two reaction products were co-cloned as explained.

\subsubsection{N-Glycosylation and Consensus Prolines}

Mutagenic primers were designed so that single point mutations were introduced in PeL sequence by site-directed mutagenesis, using $\alpha_{9 \mathrm{H} 2}-\mathrm{PeL}$ as template for the individual substitutions, $\alpha_{9 \mathrm{H} 2}-\mathrm{PeL}$ K220N for obtaining the double variant $\left(\alpha_{9 \mathrm{H} 2}-\mathrm{PeL}\right.$ K220N; E478P), and the latter for obtaining the triple variants. For each mutagenesis site two fragments were obtaining; a first fragment with the ExtFw sense primer and the corresponding antisense mutagenic primer, and the second fragment with their specific mutagenic sense 
primer and the general ExtRv antisense primer (Table S3). Same process was followed for obtaining the deglycosylated variant N255 ApL.

\subsection{Laccase Production}

\subsubsection{Flask Fermentation}

Three single $S$. cerevisiae colonies transformed with the plasmid containing a given laccase mutant were picked and inoculated in $3 \mathrm{~mL} \mathrm{MM}$ and incubated for $48 \mathrm{~h}$ at $30^{\circ} \mathrm{C}$, $200 \mathrm{rpm}$. An aliquot of the culture was used to inoculate a final volume of $10 \mathrm{~mL}(\mathrm{MM})$ in $100 \mathrm{~mL}$ flask with a final OD600 of 0.3 . After $4 \mathrm{~h}$ incubation at $30^{\circ} \mathrm{C}(\mathrm{OD} 600$ close to 1$)$, cells were diluted to OD600 $=0.1$ in $30 \mathrm{~mL}$ EB medium in $100 \mathrm{~mL}$ flask. Laccase activities secreted in the liquid extracts were measured by the oxidation of ABTS $\left(\varepsilon 418=36,000 \mathrm{M}^{-1} \mathrm{~cm}^{-1}\right)$ in citrate phosphate (CP) $100 \mathrm{mM} \mathrm{pH} \mathrm{3,} \mathrm{using} \mathrm{the} \mathrm{UV-1900} \mathrm{Shidmazu} \mathrm{spectrophotometer.}$ Maximum activity was roughly reached after 4 days of incubation at $28^{\circ} \mathrm{C}$ and 6 days at $20^{\circ} \mathrm{C}$. At that moment, cells were centrifuged at $13,000 \mathrm{rpm}, 4^{\circ} \mathrm{C}$ and the supernatants concentrated using $10 \mathrm{KDa}$ AmiconUltra Centrifugal filters at $5000 \mathrm{rpm}$ for $10 \mathrm{~min}$.

\subsubsection{Microwell Production}

Five colonies of each S. cerevisiae clone (transformed with a particular laccase variant) were picked in 96-well plates, containing $50 \mu \mathrm{L}$ of MM per well, and grown at $28{ }^{\circ} \mathrm{C}$, $225 \mathrm{rpm}$, and $80 \%$ relative humidity in a humidity shaker (Minitron-INFORS, Bottmingen, Switzerland). After $24 \mathrm{~h}, 160 \mu \mathrm{L}$ of SEM medium was added to each well, and the plates were incubated at $28^{\circ} \mathrm{C}$ for $48 \mathrm{~h}$. The plates were centrifuged (Eppendorf 5810R centrifuge, Hamburg, Germany) for $5 \mathrm{~min}$ at $3000 \mathrm{~g}$ at $4{ }^{\circ} \mathrm{C}$, and $20 \mu \mathrm{L}$ of supernatant was mixed with $180 \mu \mathrm{L}$ of $3 \mathrm{mM}$ ABTS in $100 \mathrm{mM} \mathrm{CP} \mathrm{pH} 3$. The plates were briefly stirred and laccase activity was determined in kinetic mode by the increment in Abs 418 in a plate reader SpectraMax M2 (Molecular Devices, Sunnyvale, CA, USA).

\subsection{Laccase Characterization}

\subsection{1. $\mathrm{pH}$ Activity Profile}

Optimum $\mathrm{pH}$ of crude enzymes was measured using $20 \mu \mathrm{L}$ of the concentrated supernatants (at $0.1 \mathrm{U} / \mathrm{mL}$ ) and $180 \mu \mathrm{L}$ of $3 \mathrm{mM}$ ABTS in $100 \mathrm{mM}$ Britton Robinson (BR) buffer at $\mathrm{pH} 2-8$ range. The solution was mixed and measured in kinetic mode in triplicate. Relative activities were calculated respecting the maximum activity of each laccase variant.

\subsubsection{Thermostability Assay}

T50 is defined as the temperature at which the enzyme retains $50 \%$ of its activity after a period of incubation. Samples with $0.1 \mathrm{U} / \mathrm{mL}$ of crude or purified enzyme were incubated in a 30-80 ${ }^{\circ} \mathrm{C}$ temperature gradient in a thermocycler (in triplicate) for $10 \mathrm{~min}$. After cooling the enzymes at $4{ }^{\circ} \mathrm{C}$ for $10 \mathrm{~min}$ and tempering at room temperature for another $10 \mathrm{~min}$, $20 \mu \mathrm{L}$ aliquots were mixed with $180 \mu \mathrm{L} 3 \mathrm{mM}$ ABTS in $50 \mathrm{mM} \mathrm{CP}$ buffer $\mathrm{pH} 3$ to determine laccase activity at $418 \mathrm{~nm}$ in kinetic mode. The thermostability values were calculated from the ratio between the residual activities incubated at different temperatures and the maximum activity.

\subsection{3. $\mathrm{pH}$ Stability Assay}

Aliquots of $0.1 \mathrm{U} / \mathrm{mL}$ of crude or purified enzyme were incubated in $100 \mathrm{mM}$ BR Buffer at different $\mathrm{pH}$ values (3-9) for 2, 4, 6 and $24 \mathrm{~h}$. Residual activities at different times were measured with $20 \mu \mathrm{L}$ samples and $180 \mu \mathrm{L} 3 \mathrm{mM}$ ABTS in $50 \mathrm{mM} \mathrm{CP}$ buffer $\mathrm{pH} 3$, in triplicate, in kinetic mode. The relative activity was calculated as a percentage of the initial activity.

\section{Conclusions}

The difficult heterologous expression of fungal laccases is often a bottleneck for the study and application of these green biocatalysts. Enzyme-directed evolution allows to 
tailor enzymes with enhanced robustness or catalytic activities and increase production yields. Here, we demonstrate the outstanding ability of $\alpha_{9 \mathrm{H} 2}$, a mutated $\alpha$-factor preproleader obtained through successive laccase evolution campaigns in S. cerevisiae, to enhance laccase secretion by the yeast. Mutations of the enzyme sequence can also have a positive effect on enzyme production. We evidence here the role of $N$-glycosylation on laccase production and properties, and introduce consensus mutations in the protein scaffold that allow the functional expression of particularly recalcitrant enzymes. Finally, we revise the role of synonymous mutations that ease translation efficiency or of mutations of the protein scaffold favoring protein folding and maturation.

Supplementary Materials: The following are available online at https: / /www.mdpi.com/1422-0 067/22/3/1157/s1, Figure S1: SDS-PAGE of purified ApL variants before (lane 1) and after (lane 2) removal of N255 site, showing the partial deglycosylation of the enzyme (theorical molecular weigth $50 \mathrm{KDa}$ ). Two other more putative $N$-glycosylation sites in ApL would explain the remaining glycosylation observed in lane 2. Same amounts of both purified enzymes were utilised. Table S1: Laccase activities with ABTS pH 3 and OD600 of the liquid cultures of S. cerevisiae expressing nondeglycosylated and deglycosylated (NGly255) variants of ApL at $20^{\circ} \mathrm{C}$. Table S2: Kinetic constants of purified non-deglycosylated and deglycosylated (NGly255) variants of ApL for the oxidation of ABTS, pH 3. Table S3. Sequences of the primers used. Mutated codons appear underlined.

Author Contributions: Conceptualization, S.C.; methodology, P.A., F.d.S., G.M.; validation, P.A.; formal analysis, P.A., G.M.; investigation, P.A., G.M., D.R.-E., I.d.1.F.; writing-original draft preparation, P.A. and S.C.; writing-review and editing, P.A., F.d.S., G.M. and S.C.; supervision, S.C.; funding acquisition, S.C. All authors have read and agreed to the published version of the manuscript.

Funding: This research was funded by the Spanish Project GENOBIOREF (BIO2017-86559-R) from the State R\&D Program Oriented to the Challenges of the Society, and by the European Project WOODZYMES, funded by the Bio Based Industries Joint Undertaking, under the European Union's Horizon 2020 research and innovation program (Grant Agreement H2020-BBI-JU-792070).

Institutional Review Board Statement: Not applicable.

Informed Consent Statement: Not applicable.

Data Availability Statement: The data presented in this study are contained within this article and supplementary materials.

Acknowledgments: P.A. acknowledges the Spanish Ministry of Science, Innovation and Universities for his FPU grant and G.M. acknowledges The Tatiana Pérez de Guzmán el Bueno Foundation for his predoctoral Environment grant.

Conflicts of Interest: The authors declare no conflict of interests.

\section{References}

1. Janusz, G.; Pawlik, A.; Świderska-Burek, U.; Polak, J.; Sulej, J.; Jarosz-Wilkołazka, A.; Paszczyński, A. Laccase Properties, Physiological Functions, and Evolution. Int. J. Mol. Sci. 2020, 21, 966. [CrossRef] [PubMed]

2. Jones, S.M.; Solomon, E.I. Electron Transfer and Reaction Mechanism of Laccases. Cell. Mol. Life Sci. 2015, 72, 869-883. [CrossRef] [PubMed]

3. Lucas, M.F.; Monza, E.; Jørgensen, L.J.; Ernst, H.A.; Piontek, K.; Bjerrum, M.J.; Martinez, Á.T.; Camarero, S.; Guallar, V. Simulating Substrate Recognition and Oxidation in Laccases: From Description to Design. J. Chem. Theory Comput. 2017, 13, 1462-1467. [CrossRef] [PubMed]

4. Hakulinen, N.; Rouvinen, J. Three-Dimensional Structures of Laccases. Cell. Mol. Life Sci. 2015, 72, 857-868. [CrossRef] [PubMed]

5. Piontek, K.; Antorini, M.; Choinowski, T. Crystal Structure of a Laccase from the Fungus Trametes Versicolor at 1.90- $\AA$ Resolution Containing a Full Complement of Coppers. J. Biol. Chem. 2002, 277, 37663-37669. [CrossRef]

6. Glazunova, O.A.; Polyakov, K.M.; Fedorova, T.V.; Dorovatovskii, P.V.; Koroleva, O.V. Elucidation of the Crystal Structure of Coriolopsis Caperata Laccase: Restoration of the Structure and Activity of the Native Enzyme from the T2-Depleted Form by Copper Ions. Acta Crystallogr. Sect. D Biol. Crystallogr. 2015, 71, 854-861. [CrossRef] [PubMed]

7. Maestre-Reyna, M.; Liu, W.C.; Jeng, W.Y.; Lee, C.C.; Hsu, C.A.; Wen, T.N.; Wang, A.H.J.; Shyur, L.F. Structural and Functional Roles of Glycosylation in Fungal Laccase from Lentinus Sp. PLoS ONE 2015, 10, 0120601. [CrossRef]

8. Riva, S. Laccases: Blue Enzymes for Green Chemistry. Trends Biotechnol. 2006, 24, 219-226. [CrossRef] 
9. Cassland, P.; Jönsson, L.J. Characterization of a Gene Encoding Trametes Versicolor Laccase A and Improved Heterologous Expression in Saccharomyces Cerevisiae by Decreased Cultivation Temperature. Appl. Microbiol. Biotechnol. 1999, 52, 393-400. [CrossRef]

10. Kojima, Y.; Tsukuda, Y.; Kawai, Y.; Tsukamoto, A.; Sugiura, J.; Sakaino, M.; Kita, Y. Cloning, Sequence Analysis, and Expression of Ligninolytic Phenoloxidase Genes of the White-Rot Basidiomycete Coriolus Hirsutus. J. Biol. Chem. 1990, 265, 15224-15230. [CrossRef]

11. Larsson, S.; Cassland, P.; Jönsson, L.J. Development of a Saccharomyces Cerevisiae Strain with Enhanced Resistance to Phenolic Fermentation Inhibitors in Lignocellulose Hydrolysates by Heterologous Expression of Laccase. Appl. Environ. Microbiol. 2001, 67, 1163-1170. [CrossRef] [PubMed]

12. Camarero, S.; Pardo, I.; Cañas, A.I.; Molina, P.; Record, E.; Martínez, A.T.; Martínez, M.J.; Alcalde, M. Engineering Platforms for Directed Evolution of Laccase from Pycnoporus Cinnabarinus. Appl. Environ. Microbiol. 2012, 78, 1370-1384. [CrossRef] [PubMed]

13. Faraco, V.; Ercole, C.; Festa, G.; Giardina, P.; Piscitelli, A.; Sannia, G. Heterologous Expression of Heterodimeric Laccase from Pleurotus Ostreatus in Kluyveromyces Lactis. Appl. Microbiol. Biotechnol. 2008, 77, 1329-1335. [CrossRef] [PubMed]

14. Jolivalt, C.; Madzak, C.; Brault, A.; Caminade, E.; Malosse, C.; Mougin, C. Expression of Laccase IIIb from the White-Rot Fungus Trametes Versicolor in the Yeast Yarrowia Lipolytica for Environmental Applications. Appl. Microbiol. Biotechnol. 2005, 66, 450-456. [CrossRef]

15. Gelo-Pujic, M.; Kim, H.-H.; Butlin, N.G.; Palmore, G.T.R. Electrochemical Studies of a Truncated Laccase Produced in Pichia Pastoris. Appl. Environ. Microbiol. 1999, 65, 5515-5521. [CrossRef] [PubMed]

16. Jönsson, L.J.; Saloheimo, M.; Penttilä, M. Laccase from the White-Rot Fungus Trametes Versicolor: CDNA Cloning of Lcc1 and Expression in Pichia Pastoris. Curr. Genet. 1997, 32, 425-430. [CrossRef]

17. Otterbein, L.; Record, E.; Longhi, S.; Asther, M.; Moukha, S. Molecular Cloning of the CDNA Encoding Laccase from Pycnoporus Cinnabarinus I-937 and Expression in Pichia Pastoris. Eur. J. Biochem. 2000, 267, 1619-1625. [CrossRef]

18. Saloheimo, M.; Niku-Paavola, M.L. Heterologous Production of a Ligninolytic Enzyme: Expression of the Phlebia Radiata Laccase Gene in Trichoderma Reesei. BioTechnology 1991, 9, 987-990. [CrossRef]

19. De Salas, F.; Cañadas, R.; Santiago, G.; Virseda-Jerez, A.; Vind, J.; Gentili, P.; Martínez, A.T.; Guallar, V.; Muñoz, I.G.; Camarero, S. Structural and Biochemical Insights into an Engineered High-Redox Potential Laccase Overproduced in Aspergillus. Int. J. Biol. Macromol. 2019, 141, 855-866. [CrossRef]

20. Record, E.; Punt, P.J.; Chamkha, M.; Labat, M.; Van Den Hondel, C.A.M.J.J.; Asther, M. Expression of the Pycnoporus Cinnabarinus Laccase Gene in Aspergillus Niger and Characterization of the Recombinant Enzyme. Eur. J. Biochem. 2002, 269, 602-609. [CrossRef]

21. Gonzalez-Perez, D.; Garcia-Ruiz, E.; Alcalde, M. Saccharomyces Cerevisiae in Directed Evolution: An Efficient Tool to Improve Enzymes. Bioeng. Bugs 2012, 3, 172-177. [CrossRef] [PubMed]

22. Çelik, E.; Çalik, P. Production of Recombinant Proteins by Yeast Cells. Biotechnol. Adv. 2012, 30, 1108-1118. [CrossRef] [PubMed]

23. Vieira Gomes, A.; Souza Carmo, T.; Silva Carvalho, L.; Mendonça Bahia, F.; Parachin, N. Comparison of Yeasts as Hosts for Recombinant Protein Production. Microorganisms 2018, 6, 38. [CrossRef] [PubMed]

24. Yoshitake, A.; Katayama, Y.; Nakamura, M.; Iimura, Y.; Kawai, S.; Morohoshi, N. N-Linked Carbohydrate Chains Protect Laccase III from Proteolysis in Coriolus Versicolor. Microbiology 1993, 139, 179-185. [CrossRef]

25. Christensen, N.J.; Kepp, K.P. Stability Mechanisms of a Thermophilic Laccase Probed by Molecular Dynamics. PLoS ONE 2013, 8. [CrossRef]

26. Conde, R.; Cueva, R.; Pablo, G.; Polaina, J.; Larriba, G. A Search for Hyperglycosylation Signals in Yeast Glycoproteins. J. Biol. Chem. 2004, 279, 43789-43798. [CrossRef]

27. Singh, A.; Chen, E.Y.; Lugovoy, J.M.; Chang, C.N.; Hitzeman, R.A.; Seeburg, P.H. Saccharomyces Cerevisiae Contains Two Discrete Genes Coding for the $\alpha$-Factor Pheromone. Nucleic Acids Res. 1983, 11, 4049-4063. [CrossRef]

28. De Salas, F.; Aza, P.; Gilabert, J.F.; Santiago, G.; Kilic, S.; Sener, M.E.; Vind, J.; Guallar, V.; Martínez, A.T.; Camarero, S. Engineering of a Fungal Laccase to Develop a Robust, Versatile and Highly-Expressed Biocatalyst for Sustainable Chemistry. Green Chem. 2019, 21, 5374-5385. [CrossRef]

29. Pardo, I.; Vicente, A.I.; Mate, D.M.; Alcalde, M.; Camarero, S. Development of Chimeric Laccases by Directed Evolution. Biotechnol. Bioeng. 2012, 109, 2978-2986. [CrossRef]

30. Rakestraw, J.A.; Sazinsky, S.L.; Piatesi, A.; Antipov, E.; Wittrup, K.D. Directed Evolution of a Secretory Leader for the Improved Expression of Heterologous Proteins and Full-Length Antibodies in Saccharomyces Cerevisiae. Biotechnol. Bioeng. 2009, 103, 1192-1201. [CrossRef]

31. Lin-Cereghino, G.P.; Stark, C.M.; Kim, D.; Chang, J.; Shaheen, N.; Poerwanto, H.; Agari, K.; Moua, P.; Low, L.K.; Tran, N.; et al. The Effect of $\alpha$-Mating Factor Secretion Signal Mutations on Recombinant Protein Expression in Pichia Pastoris. Gene 2013, 519, 311-317. [CrossRef] [PubMed]

32. Maté, D.; García-Burgos, C.; García-Ruiz, E.; Ballesteros, A.O.; Camarero, S.; Alcalde, M. Laboratory Evolution of High-Redox Potential Laccases. Chem. Biol. 2010, 17, 1030-1041. [CrossRef] [PubMed]

33. Bulter, T.; Alcalde, M.; Sieber, V.; Meinhold, P.; Schlachtbauer, C.; Arnold, F.H. Functional Expression of a FungallLaccase in Saccharomyces Cerevisiae by Directed Evolution. Appl. Environ. Microbiol. 2003, 69, 987-995. [CrossRef]

34. Barrero, J.J.; Casler, J.C.; Valero, F.; Ferrer, P.; Glick, B.S. An Improved Secretion Signal Enhances the Secretion of Model Proteins from Pichia Pastoris. Microb. Cell Fact. 2018, 17, 161. [CrossRef] [PubMed] 
35. Pardo, I.; Santiago, G.; Gentili, P.; Lucas, F.; Monza, E.; Medrano, F.J.; Galli, C.; Martínez, A.T.; Guallar, V.; Camarero, S. Re-Designing the Substrate Binding Pocket of Laccase for Enhanced Oxidation of Sinapic Acid. Catal. Sci. Technol. 2016, 6, 3900-3910. [CrossRef]

36. Mateljak, I.; Tron, T.; Alcalde, M. Evolved $\alpha$-Factor Prepro-Leaders for Directed Laccase Evolution in Saccharomyces Cerevisiae. Microb. Biotechnol. 2017, 10, 1830-1836. [CrossRef]

37. Pardo, I.; Rodríguez-Escribano, D.; Aza, P.; de Salas, F.; Martínez, A.T.; Camarero, S. A Highly Stable Laccase Obtained by Swapping the Second Cupredoxin Domain. Sci. Rep. 2018, 8, 15669. [CrossRef]

38. Ruiz-Dueñas, F.J.; Barrasa, J.M.; Sánchez-García, M.; Camarero, S.; Miyauchi, S.; Serrano, A.; Linde, D.; Babiker, R.; Drula, E.; Ayuso-Fernández, I.; et al. Genomic Analysis Enlightens Agaricales Lifestyle Evolution and Increasing Peroxidase Diversity. Mol. Biol. Evol. 2020, 19, msaa301. [CrossRef]

39. Vite-Vallejo, O.; Palomares, L.A.; Dantán-González, E.; Ayala-Castro, H.G.; Martínez-Anaya, C.; Valderrama, B.; Folch-Mallol, J. The Role of N-Glycosylation on the Enzymatic Activity of a Pycnoporus Sanguineus Laccase. Enzyme Microb. Technol. 2009, 45, 233-239. [CrossRef]

40. Glazunova, O.A.; Moiseenko, K.V.; Kamenihina, I.A.; Isaykina, T.U.; Yaropolov, A.I.; Fedorova, T.V. Laccases with Variable Properties from Different Strains of Steccherinum Ochraceum: Does Glycosylation Matter? Int. J. Mol. Sci. 2019, 20, 2008. [CrossRef]

41. Xu, G.; Wu, Y.; Zhang, Y.; Fang, W.; Xiao, Y.; Fang, Z. Role of N-Glycosylation on the Specific Activity of a Coprinopsis Cinerea Laccase Lcc9 Expressed in Pichia Pastoris. J. Biosci. Bioeng. 2019, 128, 518-524. [CrossRef] [PubMed]

42. Garg, N.; Bieler, N.; Kenzom, T.; Chhabra, M.; Ansorge-Schumacher, M.; Mishra, S. Cloning, Sequence Analysis, Expression of Cyathus Bulleri Laccase in Pichia Pastoris and Characterization of Recombinant Laccase. BMC Biotechnol. 2012, 12, 1-12. [CrossRef]

43. Madzak, C.; Otterbein, L.; Chamkha, M.; Moukha, S.; Asther, M.; Gaillardin, C.; Beckerich, J.M. Heterologous Production of a Laccase from the Basidiomycete Pycnoporus Cinnabarinus in the Dimorphic Yeast Yarrowia Lipolytica. FEMS Yeast Res. 2005, 5, 635-646. [CrossRef] [PubMed]

44. Han, M.; Yu, X. Enhanced Expression of Heterologous Proteins in Yeast Cells via the Modification of N-Glycosylation Sites. Bioengineered 2015, 6, 115-118. [CrossRef] [PubMed]

45. Sagt, C.M.J.; Kleiken, B.; Verwaal, R.; De Jong, M.D.M.; Muller, W.H.; SMITS, A.; Visser, C.; Boonstra, J.; Verkleij, A.J.; Verrips, C.T. Introduction of an N-Glycosylation Site Increases Secretion of Heterologous Proteins in Yeasts. Appl. Environ. Microbiol. 2000, 66, 4940-4944. [CrossRef] [PubMed]

46. Porebski, B.T.; Buckle, A.M. Consensus Protein Design. Protein Eng. Des. Sel. 2016, 29, 245-251. [CrossRef]

47. Vieille, C.; Zeikus, G.J. Hyperthermophilic Enzymes: Sources, Uses, and Molecular Mechanisms for Thermostability. Microbiol. Mol. Biol. Rev. 2001, 65, 1-43. [CrossRef]

48. Bloom, J.D.; Labthavikul, S.T.; Otey, C.R.; Arnold, F.H. Protein Stability Promotes Evolvability. Proc. Natl. Acad. Sci. USA 2006, 103, 5869-5874. [CrossRef]

49. Jäckel, C.; Bloom, J.D.; Kast, P.; Arnold, F.H.; Hilvert, D. Consensus Protein Design without Phylogenetic Bias. J. Mol. Biol. 2010, 399, 541-546. [CrossRef]

50. Matthews, B.W.; Nicholson, H.; Becktel, W.J. Enhanced Protein Thermostability from Site-Directed Mutations That Decrease the Entropy of Unfolding. Proc. Natl. Acad. Sci. USA 1987, 84, 6663-6667. [CrossRef]

51. Gomez-Fernandez, B.J.; Risso, V.A.; Sanchez-Ruiz, J.M.; Alcalde, M. Consensus Design of an Evolved High-Redox Potential Laccase. Front. Bioeng. Biotechnol. 2020, 8, 354. [CrossRef] [PubMed]

52. Li, Y.; Reilly, P.J.; Ford, C. Effect of Introducing Proline Residues on the Stability of Aspergillus Awamori. Protein Eng. 1997, 10, 1199-1204. [CrossRef] [PubMed]

53. Takano, K.; Higashi, R.; Okada, J.; Mukaiyama, A.; Tadokoro, T.; Koga, Y.; Kanaya, S. Proline Effect on the Thermostability and Slow Unfolding of a Hyperthermophilic Protein. J. Biochem. 2009, 145, 79-85. [CrossRef] [PubMed]

54. Yun, R.H.; Anderson, A.; Hermans, J. Proline in A-helix: Stability and Conformation Studied by Dynamics Simulation. Proteins Struct. Funct. Bioinform. 1991, 10, 219-228. [CrossRef]

55. Yang, J.M.; Yoneda, K.; Morita, E.; Imamura, S.; Nam, K.; Lee, E.S.; Steinert, P.M. An Alanine to Proline Mutation in the 1A Rod Domain of the Keratin 10 Chain in Epidermolytic Hyperkeratosis. J. Investig. Dermatol. 1997, 109, 692-694. [CrossRef] [PubMed]

56. Law, E.C.; Wilman, H.R.; Kelm, S.; Shi, J.; Deane, C.M. Examining the Conservation of Kinks in Alpha Helices. PLoS ONE 2016, 11, 0157553. [CrossRef]

57. Yoshimura, S.H.; Hirano, T. HEAT Repeats-Versatile Arrays of Amphiphilic Helices Working in Crowded Environments? J. Cell Sci. 2016, 129, 3963-3970. [CrossRef]

58. Kumeta, M.; Konishi, H.A.; Zhang, W.; Sakagami, S.; Yoshimura, S.H. Prolines in the $\alpha$-Helix Confer the Structural Flexibility and Functional Integrity of Importin- $\beta$. J. Cell Sci. 2018, 131. [CrossRef]

59. Ge, M.; Pan, X.M. The Contribution of Proline Residues to Protein Stability Is Associated with Isomerization Equilibrium in Both Unfolded and Folded States. Extremophiles 2009, 13, 481-489. [CrossRef]

60. Das, M.; Basu, G. Glycine Rescue of $\beta$-Sheets from Cis-Proline. J. Am. Chem. Soc. 2012, 134, 16536-16539. [CrossRef]

61. Kuncha, S.K.; Mazeed, M.; Singh, R.; Kattula, B.; Routh, S.B.; Sankaranarayanan, R. A Chiral Selectivity Relaxed Paralog of DTD for Proofreading TRNA Mischarging in Animalia. Nat. Commun. 2018, 9, 1-13. [CrossRef] [PubMed] 
62. Cusano, A.M.; Mekmouche, Y.; Meglecz, E.; Tron, T. Plasticity of Laccase Generated by Homeologous Recombination in Yeast. FEBS J. 2009, 276, 5471-5480. [CrossRef] [PubMed]

63. Vicente, A.I.; Viña-Gonzalez, J.; Santos-Moriano, P.; Marquez-Alvarez, C.; Ballesteros, A.O.; Alcalde, M. Evolved Alkaline Fungal Laccase Secreted by Saccharomyces Cerevisiae as Useful Tool for the Synthesis of C-N Heteropolymeric Dye. J. Mol. Catal. B Enzym. 2016, 134, 323-330. [CrossRef]

64. Romanos, M.A.; Scorer, C.A.; Clare, J.J. Foreign Gene Expression in Yeast: A Review. Yeast 1992, 8, 423-488. [CrossRef] [PubMed]

65. Tuller, T.; Waldman, Y.Y.; Kupiec, M.; Ruppin, E. Translation Efficiency Is Determined by Both Codon Bias and Folding Energy. Proc. Natl. Acad. Sci. USA 2010, 107, 3645-3650. [CrossRef] [PubMed]

66. Waterhouse, A.; Bertoni, M.; Bienert, S.; Studer, G.; Tauriello, G.; Gumienny, R.; Heer, F.T.; De Beer, T.A.P.; Rempfer, C.; Bordoli, L.; et al. SWISS-MODEL: Homology Modelling of Protein Structures and Complexes. Nucleic Acids Res. 2018, 46, W296-W303. [CrossRef] [PubMed]

67. Armenteros, J.J.A.; Tsirigos, K.D.; Sønderby, C.K.; Petersen, T.N.; Winther, O.; Brunak, S.; von Heijne, G.; Nielsen, H. SignalP 5.0 Improves Signal Peptide Predictions Using Deep Neural Networks. Nat. Biotechnol. 2019, 37, 420-423. [CrossRef]

68. Crooks, G.E.; Hon, G.; Chandonia, J.M.; Brenner, S.E. WebLogo: A Sequence Logo Generator. Genome Res. 2004, 14, 1188-1190. [CrossRef]

69. Puigbo, P.; Guzman, E.; Romeu, A.; Garcia-Vallve, S. OPTIMIZER: A Web Server for Optimizing the Codon Usage of DNA Sequences. Nucleic Acids Res. 2007, 35, 126-131. [CrossRef]

70. Alcalde, M.; Zumarraga, M.; Polaina, J.; Ballesteros, A.; Plou, F. Combinatorial Saturation Mutagenesis by In Vivo Overlap Extension for the Engineering of Fungal Laccases. Comb. Chem. High Throughput Screen. 2006, 9, 719-727. [CrossRef] 